\title{
THE DEFENSE OF ENTRAPMENT IN THE FEDERAL COURTS
}

\author{
Lester B. OrFIeLD*
}

Since 1932, the defense of entrapment has been firmly established in the federal courts; however, the doctrine itself is replete with basic confusion. In recent years, this underlying confusion has prompted the development of disparate rules governing the scope and application of the defense.

\section{EARLy AMERIGAN CASES}

$T$

HE DOCTRINE of entrapment was a relative late-comer to the federal courts, ${ }^{1}$ and its incipient growth was surrounded by confusion concerning both the elements necessary to constitute the defense and the theory on which the courts were to set aside a conviction where acts explicitly proscribed by criminal statutes had undoubtedly been performed by the defendant. In fact, the early cases do not even appear to recognize the term "entrapment" as a word of art;" rather, the concept developed from the relatively obscure bodies of law designated "decoys"3 or "inducements."4

- Professor of Law, Indiana University. A.B., 1924, LL.B., 1927, University of Minnesota; M.A., 1928, Duke University; S.J.D., 1929, University of Michigan. Member, United States Supreme Court Advisory Committee on Rules of Criminal Procedure, 1941-1946; Consultant, American Law Institute Model Code of Evidence, 1939-1942; Author, Cruminal Procedure UNDER the Federal Rules (1966) (two volumes of projected six-volume treatise), Criminal Procedure from ARrest to Appeal (1947), Criminal Appeals in America (1939).

${ }^{1}$ In a number of early cases the factual situations seemed to present the issue of entrapment, but since the courts did not appear to recognize the defense, the defendants failed to raise it. See United States v. Foye, 25 Fed. Cas. 1198 (No. 15157) (C.C.D. Mass. 1853); United States v. Cottingham, 25 Fed. Cas. 673 (No. 14872) (C.C.N.D.N.Y. 1852).

- Exemplary of the absence of a fixed terminology was the allegation of the defendant in Nutter v. United States, 289 Fed. 484 (4th Cir. 1923), that his conviction should be set aside because he was "tempted or entrapped." See United States v. Pappagoda, 288 Fed. 214, 216 (D. Conn. 1923): "It is true that the accused was entrapped by the action of the government agents, but this does not necessarily indicate that the government officers lured the defendant, or incited or induced him to do what he would not have done, in the absence of the actions of the government agents."

${ }^{3}$ E.g., United States v. Healy, 202 Fed. 349, 350 (D. Mont. 1913) ("Decoys are permissible to entrap criminals, but not to create them").

- Woo Wai v. United States, 223 Fed. 412, 415 (9th Cir. 1915). See also Peterson v. United States, 255 Fed. 433 (9th Cir. 1919) ("incited ... and lured"); People v. Braisted, 13 Colo. App. 532, 58 Pac. 796 (1899) ("instigated and contrived"). 
Perhaps fortuitously, early judicial discussions of the defense were aided by recognition of an analogy to the common law defense of "consent." 'Thus, in United States $v$. Whittier, the court relied upon an English robbery case $e^{\theta}$ in which the consent of the victim was proved and held that a conviction for sending contraceptive information through the mails would be reversed where the defendant had been induced by the Government to transmit the matter to a nonexistent person. ${ }^{7}$ However, the concurring opinion in Whittier refused to adopt the consent analogy and treated the case as one of first impression. It was felt that "no court should, even to aid in detecting a supposed offender, lend its countenance to . . . contrivances for inducing a person to commit a crime."8 Thus, although it was acknowledged that traditional legal principles would not suffice to dispose of convictions secured through entrapment, no concrete delineation of the new doctrine was provided. ${ }^{\circ}$

In United States $v$. Adams, ${ }^{10}$ another conviction based upon illegal use of the mails was reversed in an opinion which stressed the solicitations of the Government official and the apparent reluctance of the accused to commit the offense on his own. ${ }^{11}$ A defense based

${ }^{8} 28$ Fed. Cas. 591 (No. 16688) (C.C.E.D. Mo. 1878).

- The Case of Macdaniel, Fost. 121, 168 Eng. Rep. 60 (P.C. 1755).

T The court reasoned that because the addressee was non-existent, there had been no "giving of information" within the meaning of the statute, Act of July 12, 1876, ch. 186, 19 Stat. 90 (now 18 U.S.C. $\$ 1461$ (1964)). 28 Fed. Cas. at 593.

The concept of consent arose in another context relevant to entrapment. It was suggested that where the government, through its agents procured a crime, the sanction of the government vitiated criminal liability on the theory that volenti non fit injuria. People v. Mills, 178 N.Y. 274, 295, 70 N.E. 786, 793 (1904) (dissenting opinion).

${ }^{8} 28$ Fed. Cas. at 594 . In the same year in which Whittier was decided, two Michigan Supreme Court judges concurring in the reversal of a breaking and entering con. viction mentioned the "utterly indefensible" conduct of the police in lending aid to the defendant for purposes of prosecution. Saunders v. People, 38 Mich. 218, 222 (1878) (concurring opinion).

- Several cases involving entrapment followed Whittier, but none of them excused the defendant on that ground, although the official conduct involved was denounced in dictum. United States v. Jones, 80 Fed. 513 (C.C.E.D. Va. 1897); Unitcd States v. Grimm, 50 Fed. 528 (E.D. Mo. 1892), aff'd, 156 U.S. 604 (1895); United States v. Rapp, 30 Fed. 818, 822 (C.C.N.D. Ga. 1887). However, some judges thought the use of decoy letters for postal offenses was essential. United States v. Dorsey, 40 Fed. 752, 754 (S.D. Miss. 1889); United States v. Wight, 38 Fed. 106, 109 (E.D. Mich. 1889); see Goode v. Lnited States, 159 U.S. 663, 669 (1895).

2059 Fcd. 674 (D. Ore. 1894).

"In its reasoning, the court emphasized the concurring opinions in Whittier and People v. Saunders, 38 Mich. 218 (1878). In Grimm v. United States, 156 U.S. 604 (1895), the Court, in the context of another decoy letter case, distinguished Adams as applying only to a situation where it is "the purpose of the post office inspector to 
upon entrapment was raised in several subsequent state cases, usually without success, although undue government persuasion does not appear to have been present in most of them. ${ }^{12}$ In United Siates $v$. Healy, ${ }^{13}$ the emerging doctrine of entrapment became at the saine time both clearer and more obscure. The defendant's conviction for illegally selling liquor to an Indian was reversed when it appeared that federal agents had disguised an Indian as a non-Indian in order to elicit the criminal act. Without condoning a person who knew that he was selling to an Indian, ${ }^{14}$ the court held that the defendant was relieved of statutory punishment

by the government's invitation, which is of the nature of fraudulent concealment and deceit, and, if not consent, yet doth work an estoppel. Though the seller has violated the statute, he was the passive instrument of the government and his is a blameless wrong for which he cannot be justly convicted. ${ }^{15}$

The next major step in the progression came in Woo Wai $v$. United States, ${ }^{16}$ where a conviction for criminal conspiracy was reversed upon a showing that Government agents had induced the defendant to embark upon a program to import Chinese labor in

induce or solicit the commission of a crime, but [not where the object is] . . to ascertain whether the defendant was engaged in an unlawful business." Id. at 610 .

12 E.g., City of Evanston v. Myers, 172 Ill. 266, 50 N.E. 204 (1898) (city furnished money for liquor purchase); State v. Lucas, 94 Mo. App. 117, 67 S.W. 971 (1902) (dramshop law violated). In DeGraff v. State, 2 Okla. Crim. 519, 103 Pac. 538 (1909), the court rejected the defense, and in State v. Smith, 152 N.C. 763, 67.S.E. 922 (1910), the court refused to impute wrongful conduct to the state.

However, in a series of Colorado cases the courts refused, as contrary to public morals, to allow municipalities to recover fines from liquor sales offenses where it was apparent that the sales had been induced primarily for the purpose of obtaining prosecutions and increasing revenues. Wilcox v. People, 17 Colo. App. 109, 67 Pac. 343 (1902); People v. Braisted, 13 Colo. App. 532, 58 Pac. 796 (1899); Ford v. City of Denver, 10 Colo. App. 500, 51 Pac. 1015 (1898). An early Pennsylvania case reversed a conviction for subornation of perjury where the defendant had attempted to affect the testimony of a government agent. Commonwealth v. Bickings, 12 Pa. Dist. 206 (Q.S. Philadelphia County 1909). "Such a proceeding is not a reality, but merely a tragical farce, in which the detective, masquerading as a criminal, captivates the unsophisticated defendant, and then, with mock heroics, denounces him." Id. at 207. See People v. Mills, 178 N.Y. 274, 70 N.E. 786 (1904), where the majority affirmed a conviction over an allegation of entrapment on the grounds that the criminal design originated in the mind of the defendant. One dissenting judge thought that the state "should be estopped, as is a private individual, who seeks to induce a person by scheme or device to commit a crime." Id. at 309, 70 N.E. at 799 (dissenting opinion).

${ }^{13} 202$ Fed. 349 (D. Mont. 1913).

14 Id. at 350 . Since the offense in Healy was one of strict liability, no criminal intent was necessary. See Voves v. United States, 249 Fed. 191 (7th Cir. 1918).

16202 Fed. at 350 .

${ }^{10} 223$ Fed. 412 (9th Cir. 1915). 
violation of the federal laws. There was evidence that the degree of persuasion was substantial, ${ }^{17}$ that protections from prosecution were assured, ${ }^{18}$ and that the defendant was reluctant to accede to the pleas. ${ }^{19}$ The court found that no conspiracy had been proved but went on to hold in the alternative that

it is against public policy to sustain a conviction obtained in a manner which is disclosed by the evidence in this case [and] ... a sound public policy can be upheld only by denying the criminality of those who are thus induced to commit acts which infringe the letter of the criminal statutes. ${ }^{20}$

In the years following Woo Wai the number of cases involving the defense of entrapment increased geometrically, ${ }^{21}$ but the contours of the defense remained vague. ${ }^{22}$ The first opportunity which the Supreme Court had after Woo Wai to dispel the confusion arose in Casey $v$. United States. ${ }^{23}$ In that case, however, since the defense had not been raised at trial, the Court refused to consider it on appeal. ${ }^{24}$

${ }^{17}$ Id. at $419-14$.

${ }^{28}$ Ibid.

10 Ibid.

${ }^{20} I d$. at 415 . In $W 00 W a i$, the court made a clear distinction between the failure to find all the elements of the alleged crime and excusing the defendant where the government conduct was reprehensible.

Two explanations for the trend culminating in Woo Wai are possible. First, the absence of some element of the crime, a technical factor present in many of the cases as an alternative ground for decision, was neither satisfying to the underlying sense of justice nor always available. Second, it must have become apparent that judicial dicta condemning improper government practices were having no great impact upon official conduct. It was perhaps inevitable that, with new liquor and narcotics laws and the establishment of special agencies to enforce them, a point would be reached where some particularly odious conduct would lead to a refusal by the courts to con. vict. See Donnelly, Judicial Control of Informants, Spies, Stool Pigeons, and Agent Prov. ocateurs, 60 YALE L.J. 1091, 1099 \& n.22 (1951).

${ }^{21}$ See Annot., 18 A.L.R. 146 (1922). The federal cases on entrapment up to 1931 are listed in O'Brien v. United States, 51 F.2d 674, 678 n.l (7th Cir. 1931).

${ }^{22}$ See, e.g., Scriber v. United States, 4 F.2d 97 (6th Cir. 1925). Courts continued to differ as to the basis of the defense. Compare United States v. Eman Mfg. Co., 271 Fed. 353 (D. Colo. 1920) and United States v. Echols, 253 Fed. 862 (S.D. Tex. 1918), with Newman v. United States, 299 Fed. 128 (4th Cir. 1924) and United States v. Lynch, 256 Fed. 983 (S.D.N.Y. 1918). The rule developed that entrapment was a question for the jury, Butts v. United States, 273 Fed. 35 (8th Cir. 1921); Peterson v. United States, 255 Fed. 433 (9th Cir. 1919), unless insufficient evidence of entrapment was offered, Hall v. United States, 46 F.2d 461 (4th Cir. 1981); Vamvas v. United States, 13 F.2d 347 (5th Gir. 1926). See notes $175-85$ infra and accompanying text.

28276 U.S. 413 (1928).

st Mr. Justice Brandeis dissented, finding it of no consequence that the defense was raised for the first time on appeal: "This prosecution should be stopped, not because some right of Casey's has been denied, but in order to protect the Government. To 
It was not until 1932 in Sorrells $v$. United States ${ }^{2 \sigma}$ that the Supreme Court finally stepped in to establish the theory on which the defense was to rest and to indicate in general terms the conditions precedent to its proper invocation. ${ }^{28}$ While Sorrells firmly embedded the defense in federal criminal law, full formulation of the doctrine is still not altogether complete.

\section{Elements of the Defense}

By the time that Sorrells was decided, the federal courts had arrived at a relatively certain definition of entrapment ${ }^{27}$ which was enunciated in Mr. Justice Roberts' concurring opinion as follows:

Entrapment is the conception and planning of an offense by an officer, and his procurement of its commission by one who would not have perpetrated it except for the trickery, persuasion, or fraud of the officer. ${ }^{28}$

However, application of this definition with its obscure distinctions has baffled the courts and has prompted vague instructions to the jury. ${ }^{29}$ Minor variations apparently desigued to render the test more concrete have thus been suggested. In much-quoted language, ${ }^{30} \mathrm{Mr}$.

protect it from illegal conduct of its offcers, To preserve the purity of its courts." Id. at 425 (dissenting opinion).

25287 U.S. 435 (1932).

${ }^{20}$ In Sorrells, the Court unanimously held that entrapment had not been disproved as a matter of law and that it was error for the trial court not to submit the issue of entrapment to the jury. The Court was split 5-4, however, on the critical question of the basis of the defense. See notes 114-18 infra and accompanying text.

${ }^{27}$ See Sorrells v. United States, 57 F.2d 973, 978 n.I (4th Cir.) (collecting cases), rev'd, 287 U.S. 435 (1932).

28 287 U.S. at 454. The court concluded that entrapment exists when the criminal design has originated in the mind of the government agent and has been planted in the mind of an innocent person in order that a prosecution may be instituted.

Sorrells $v$. United States was noted in Nate, 13 B.U.L. REv. 293 (1933); Note, 38 Dick. L. Rev. 191 (1933); Note, I Geo. Wash. L. Rev. 371 (1933); Note, 12 OrE. L. REv. 313 (1933); Note, 1 U. CHI. L. REv. 115 (1939); Note, 42 Yale L.J. 803 (1933); 46 HaRv. L. REv. 848 (I933); 31 MICH. L. REv. 1159 (1933); 10 N.Y.U.L.Q. REv. 533 (1939); II TEX. L. REv. 385 (1933); 39 W. VA. L. REv. 261 (1933). See generally Mikell, The Doctrine of Entrapment in the Federal Courts, 90 U. PA. L. REv. 245 (1942). See also United States .v. Head, 353 F.2d 566 (6th Cir. 1965); United States v. Gaines, 353 F.2d 276 (6th Cir. 1965); United States v. Clarke, 343 F.2d 90 (3d Cir. 1965).

so Sherman v. United States, 356 U.S. 369, 378 (1958) (Frankfurter, J., concurring). See, e.g., Lucas v. United States, 355 F.2d 245 (10th Cir.), cert. denied, 384 U.S. 977 (1966); United States v. Becker, 62 F.2d 1007, 1009 (2d Cir. 1933); State v. Groulx, 106 N.H. 44, 203 A.2d 641 (1964).

${ }^{80}$ E.g., Lucas v. United States, supra note 29; United States v. Gaines, 353 F.2d 276 (6th Cir. 1965); United States v. Clarke, 343 F.2d 90 (3d Cir. 1965); United States v. Accardi, 257 F.2d 168 (5th Cir.), cert. denied, 358 U.S. 883 (1958); State v. Thurston, 100 Ariz. 297, 413 P.2d 764 (1966). 
Chief Justice Warren explained that "entrapment occurs only when the criminal conduct was 'the product of the creative activity' of law enforcement officials [and that] ... a line must be drawn between the trap for the unwary innocent and the unwary criminal."s1 Quite expectedly, these further delineations added little to the elusive doctrine.

More recently, Mr. Justice Harlan commented,

Thus before the issue of entrapment can fairly be said to have been presented in a criminal prosecution there must have been at least some showing of the kind of conduct by government agents which may well have induced the accused to commit the crime charged. ${ }^{32}$

While this formulation, like the one set forth by the Model Penal Code, $^{33}$ does suggest the type of proof necessary to establish entrapment, it makes no real advance. in distinguishing impermissible "inducement" from allowable "opportunity," forbidden "trickery" from acceptable "strategem," or the "unwary innocent" from the "unwary criminal." The absence of meaningful distinctions is further complicated by the fact that two of the necessary elementsoriginal conception of the plan and actual inducement of the defendant-direct the trier of fact to examine the defendant's state of mind.

In their efforts to determine the situations to which the doctrine will apply, the courts have attempted to atomize the defense into its requisite components and thereby render it somewhat more manageable. ${ }^{34}$ In the abstract, at least, the defense may be conveniently dissected into four constituent elements: first, a government officer or agent must instigate the offense; second, government agents must perform acts constituting inducement; third, the inducements offered

31 Sherman v. United States, 356 U.S. 369, 372 (1958). (Emphasis in original.)

32 Lopez v. United States, 373 U.S. 427, 434-35 (1963).

a Modez Penal Codé $\$ 2.13$ (Proposed Official Draft 1962).

"A public law enforcement official or a person acting in co-operation with such an official perpetrates an entrapment if for the purpose of obtaining evidence of the commission of an offense, he induces or encourages another person to engage in conduct constituting such offense by either:

“ (a) making knowingly false representations designed to induce the belief that such conduct is not prohibited; or

“ (b) employing methods of persuasion or inducement which create a substantial risk that such an offense will be committed by persons other than those who are ready to commit it."

3' See, e.g., State v. Thurston, 100 Ariz. 297, 413 P:2d 764 (1966). 
by the government must cause the defendant's conduct; and finally, the criminal design must not originate in the mind of the defendant.

\section{Participation of government agent}

Because a central policy behind the defense is the protection of "public confidence in the fair and honorable administration of justice"ss which may well be threatened if the courts permit "enforcement of the law by lawless means," 38 the person who induces the accused to commit the crime must be a government officer ${ }^{37}$ or an agent of the government. ${ }^{38}$ There may be entrapment in a federal prosecution even though the act of inducement was performed by a state officer not acting under the direction of or in collaboration with any federal officer. ${ }^{38}$ However, there can be no entrapment when a private person induces the defendant's acts, even where he uses the most insidious forms of fraud and trickery..$^{10}$

\footnotetext{
${ }^{36}$ Sherman v. United States, 356 U.S. 369, 380 (1958) (Frankfurter, J., concurring). so Ibid.

${ }^{87}$ E.g., Lopez v. United States, 273 U.S. 427, 434-35 (1963); Sherman v. United States, 356 U.S. 369, 372 (1958); Sorrells v. United States, 287 U.S. 435,442 (1932).

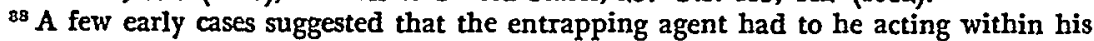
actual authority for the entrapment defense to be available, since deviation from the government directions was thought not to be the government's responsibility. See Hayes v. United States, 112 F.2d 676, 677 (10th Cir. 1940); Kendjerski v. United States, 9 F.2d 909, 910 (6th Cir. 1926).

Other cases, which appear to represent the majority, give the government agent what amounts to general authority and permit the defendant to raise the defense even though the government officials did not sanction the particular conduct. E.g., United States ex rel. Hassel v. Mathues, 22 F.2d 979 (E.D. Pa. 1927).

One line of distinction has been drawn by the courts which makes decisive the fact of the knowledge of the inducing person. Several decisions have held that where a government agent has procured the commission of an offense by presenting the opportunity to an unwitting third party, who, in turn and without specific direction by the government agent, induces participation in the offense hy the defendant, the third party's inducement of the defendant's crime cannot be attributed to the government but inust he treated as the urgings of a private individual. United States v. Comi, 336 F.2d 856, 860 (4th Cir.), cert. denied, 379 U.S. 992 (1964); United States v. Romano, 278 F.2d 202, 204 (2d Cir. 1960); Crisp v. United States, 262 F.2d 68 (4th Cir. 1958). However, it has been held that where the government officials have entrapped $X, X$ may become a government agent for the purpose of entrapping his partner $Y$, and $Y$. can raise the defense. United States v. Klosterman, 248 F.2d 191 (3d Cir. 1957). But see United States v. Perkins, 190 F.2d 49 (7th Cir. 1951). See also Note, 45 B.U.L. REv. 542, 563-64 (1965).

The types of persons often employed by the government as agents and the methods by which the groernment employs them often serve to enhance the aggravating features of the government role in the prosecution. See notes 136-48 infra and accompanying text.

${ }^{39}$ E.g., Henderson v. United States, 237 F.2d 169, 176 (5th Cir. 1956); Billingsley v. United States, 274 Fed. 86 (6th Cir.), cert. denied, 257 U.S. 656 (1921).

${ }^{10}$ See, e.g., Sherman v. United States, 356 U.S. 369 (1958); Sorrells v. United States,
} 


\section{Government acts constituting inducement}

Acts of government agents which will constitute the necessary "inducement" may assume a variety of guises. Employment of fraud, trickery, or persuasion is broadly condemned and will support a finding of inducement.41 In contrast, mere "stealth" and "strategem" designed to provide the defendant an "opportunity" to act criminally are condoned"2 as "necessary weapons in the arsenal of the police officer."43 Similarly, mere deception by the government agent, whereby artifice is used to conceal his official identity, does not always amount to sufficient inducement.44 Yet, such deception may suffice ${ }^{45}$ since "decoys are permissible to entrap criminals but not to create them." 40 But where the defendant knows that the person with whom he deals is a government officer, any inference of inducement may be negated. 47

287 U.S. 495 (1932); Johnson v. United States, 317 F.2d 127, 128 (D.C. Cir. 1963); Henderson v. United States, 237 F.2d 169, 175 (5th Cir. 1956); Papadakis v. United States, 208 F.2d 945, 954 (9th Cir. 1953).

"See Sherman v. United States, supra note 40, at 373; id. at 384 (concurring opinion); Sorrells v. United States, supra note 40, at 454; United States v. Gaines, 359 F.2d 276, 278 (6th Cir. 1965); United States v. Gosser, 339 F.2d 103 (6th Cir. 1964), cert. denied, 382 U.S. 819 (1965).

4 Sherman v. United States, supre note 40; United States v. Gosser, supra note 41; People v. Ramos, 146 Cal. App. 2d 110, 303 P.2d 783 (Dist. Ct. App. 1956).

"The defense of entrapment is not available to one standing ready to commit an offense "given an opportunity." Bloch v. United States, 226 F.2d 185 (9th Cir. 1955); see Annot., 33 A.L.R.2d 883 (1954).

"Sherman v. United States, supra note 40 , at 372.

" E.g., Sorrells v. United States, 287 U.S. 435, 441 (1932); Benson v. California, 336 F.2d 791 (9th Cir.), cert. denied, 380 U.S. 951 (1964); Kivette v. United States, 230 F.2d 749, 754 (5th Cir.), cert. denied, 355 U.S. 935 (1956); Zucker v. United States, 288 Fed. 12, 16 (3d Cir.), cert. denied, 262 U.S. 756 (1923).

"There may be inducement, however, where the actual identity of the agent is a material fact as to guilt. Thus, where a government agent who was an Indian disguised his identity to purchase liquor, there was inducement. United States v. Healy, 202 F.2d \$49 (D. Mont. 1913); cf. Hayes v. United States, 112 F.2d 676 (10th Cir. 1940); see also Voves v. United States, 249 Fed. 191 (7th Cir. 1918); Model Penal Code \$2.13 (Pro. posed Official Draft 1962).

40 United States v. Healy, supra note 45 , at 350 .

${ }^{4}$ E.g., Reid v. United States, 334 F.2d 915 (9th Cir. 1964); People v. Estrada, 211 Cal. App. 2d 722, 27 Cal. Rptr. 605 (Dist. Ct. App. 1963).

An obvious and substantial exception to the no-concealment rule, however, is the application of the defense to bribery. Entrapment may lie where a government officer demands a bribe, and an otherwise innocent person who fears official retaliation might yield to such a demand. Capuano v. United States, 9 F.2d 41 (lst Cir. 1925); United States v. Mathues, 22 F.2d 979 (E.D. Pa. 1927). But cf. Scriber v. United States, 4 F.2d 97 (6th Cir. 1925).

To be distinguished from these cases are those involving the related defense of coercion by public officers. See United States v. Lynch, 256 Fed. 983, 984-85 (S.D.N.Y. 1918). 
Understandably, finders of fact, guided only by these oblique criteria, are cast upon a no-man's land. It may therefore, be instructive at this point to catalogue certain particular acts which have been found to constitute inducement. For example, a mere tender of the purchase price by the government does not establish the inducement necessary to support entrapment in the illegal sale.48 Likewise, providing the defendant with the necessary and requested means to commit an offense is not in itself an inducement, ${ }^{49}$ but all the surrounding facts and circumstances of the procurement of the crime must be considered. ${ }^{50}$ Entrapment has been found where the acts of inducement consisted of pleas to relieve desperate illness, ${ }^{51}$ offers of large sums of money, ${ }^{52}$ or contrived and persistent coaxing. ${ }^{53}$ Stated generally, prohibited inducement "includes soliciting, proposing, initiating, broaching or suggesting the commission of the offense charged."54

Perhaps a more effective approach to inducement is the functional one whereby the sufficiency of the inducement is measured by its actual impact upon the defendant. Thus, "any effective appeal to the impulses of compassion, sympathy, pity, friendship, fear, or hope, other than the ordinary expectation of gain or profit" will be enough. ${ }^{55}$ Some cases suggest that government conduct which is

${ }^{8}$ E.g., Smith v. United States, 331 F.2d 784, 790 (D.C. Cir. 1964); Bakotich v. United States, 4 F.2d 386, 387 (9th Cir. 1925). There is merely a permissible trap where the government offer merely serves to "expose [the defendant] ... to what might be called the ordinary degree of temptation." Scriber v. United States, supra note 47, at 98 .

0 United States v. Roett, 172 F.2d 379 (3d Cir.), cert. denied, 336 U.S. 960 (1949).

so See Johnson v. United States, 317 F.2d 127 (D.C. Cir. 1963) (providing the defendant with six dollars and transportation necessary to purchase narcotics could constitute inducement).

${ }^{51}$ E.g., Wall v. United States, 65 F.2d 993 (5th Cir. 1933); Driskill v. United States, 24 F.2d 525 (9th Cir. 1928); Butts v. United States, 273 Fed. 35 (8th Cir. 1921).

${ }_{58}$ E.g., Morei v. United States, 127 F.2d 827, 834 (6th Cir. 1942); United States v. Wray, 8 F.2d 429 (N.D. Ga. 1925).

${ }^{88}$ E.g., Sherman v. United States, 356 U.S. 369 (1958); United States v. Gaines, 353 F.2d 276 (6th Cir. 1965); Hattem v. United States, 283 F.2d 339 (9th Cir. 1960); Woo Wai v. United States, 223 Fed. 412 (9th Cir. 1915). Contra, People v. Hawkins, 210 Cal. App. 2d 669, 27 Cal. Rptr. 144 (Dist. Ct. App. 1963); People v. Toler, 26 Ill. 2d 100, 185 N.E.2d 874, cert. denied, 374 U.S. 813 (1963).

84 United States v. Sherman, 200 F.2d 880, 883 (2d Cir. 1952).

${ }^{65}$ United States v. Washington, 20 F.2d 160, 163 (D. Neb. 1927). See Note, 33 N.Y.U.L. REv. 1039, 1035 (1958). Contra, People v. Hatch, 49 I1l. App. 2d 177, 199. N.E.2d 81 (1964).

- In keeping with the quoted language is Sagansky v. United States, 358 F.2d 195, 202 (lst Cir. 1966), in which prompting a local gambler to utilize interstate communications facilities in order to procure a federal conviction was held to constitute illegal inducement. 
outrageous will, without more, dictate a finding of entrapment, but no court has found entrapment on these grounds alone. ${ }^{67}$ However, under any approach a government agent who merely conducts himself in a manner typical of victims of crime does not thereby induce its commission. ${ }^{58}$

Before the government may legitimately offer an inducement to a future defendant, the federal courts have required, albeit irregularly, that the government have some knowledge at the time of the offer that its target might respond to a criminal suggestion. ${ }^{59}$ This requirement provides some safeguard against the possibility that the government, by capitalizing on anyone's particular weakness, could make criminals of everyone. However, the application of this prerequisite has not been uniform. Some courts indicate that governmental suspicion of a criminal propensity is a condition precedent which the government must demonstrate in addition to its showing of defendant's actual predisposition, ${ }^{60}$ while others view it as an

86.Waker v. United States, 344 F.2d 795 (1st Cir. 1965); Whiting v. United States, 321 F.2d 72, 76 \& n.8 (1st Cir.), cert. denied, 375 U.S. 884 (1963).

57 The First Circuit in Whiting v. United States, supra note 56, stated that once in. ducement had been shown, the Government could prove that there was no entrapment by showing that the inducements were not offensive per se and that the defendant was not actually corrupted by the solicitations. See note 195 infra.

s8 Vaccaro v. Collier, 88 F.2d 862, 870 (D. Md. 1930) (pretended morphine addict); People v. Johnson, 66 Ill. App. 2d 465, 214 N.E.2d 354 (1966) (robbery target).

${ }^{\circ}$ The requirement of prior knowledge could well be considered, at least con. ceptually, as a separate aspect of the defense, designed to check arbitrary police in. trusion upon citizens. However, the cases are unclear both as to the role which the requirement assumes in the defense and as to the primary purpose which it serves. Frequently, the context in which the courts observe that the police had sufficient prior knowledge makes its difficult to tell whether the requirement is an independent one or is related to the elements of conception or actual inducement.

While the imposition of any theoretical superstructure upon the cases runs the risk of finding logic where none exists, a consideration of the possible bases for any prior-knowledge requirement does point to a possibly helpful formulation consistent with the policies which prompted recognition of the defense-discouragement of objectionable official conduct and protection of its victim. Requiring the government to have grounds to suspect the target of their prosecution-oriented drama would seem to produce results compatible with notions of fair play. Compare Accardi $v$. United States, 257 F.2d 168, 172 (5th Cir.), cert. denied, 358 U.S. 883 (1958). This judgment is reinforced by reference to the degree of knowledge prerequisite to any valid arrest or search and seizure. Thus, the failure of the government to show that it had reasonable grounds to suspect the defendant of a course of criminal conduct, an example of which they induced, ought to vitiate the criminality of the act so secured.

${ }^{\circ 0}$ See Trice v. United States, 211 F.2d 513 (9th Cir.), cert. denied, 348 U.S. 900 (1954); Heath v. Unitcd States, 169 F.2d 1007, 1010 (10th Cir. 1948); O'Brien v. United States, 51 F.2d 674, 680 (7th Cir. 1981); Billingsiey v. United States, 274 Fed. 86, 89 (6th Cir.), cert. denied, 257 U.S. 656 (1921); United States v. Owens, 228 F. Supp. 300 (D.D.C. 1964); United States v. Siegel, 16 F.2d 134 (D. Minn. 1926) (semble). 
alternative means by which the government can completely justify the most obnoxious inducement of a defendant who was not actually predisposed. $^{01}$ Nor is the extent of prior knowledge which the government must possess firmly established. Although some courts have discussed the requirement as one of "probable cause" to suspect the defendant, 62 the general view is that if the government can prove that it had a reasonable suspicion of the criminal predisposition, its activities will be justified. ${ }^{63}$

A synthesis of the cases, however, suggests a possible test: if the trap into which the defendant falls is aimed at the community in general, there is no inducement but only a permissible "opportunity" afforded to the defendant to commit the prohibited act. On the other hand, there is inducement where one person or a group of persons are subjected to the temptation without prior governmental knowledge amounting to a reasonable suspicion. Moreover, even if

Requiring the government to show not only that the defendant was predisposed to commit the crime but also that the government knew he was so inclined before the inducement was offered would appear to be justified, since government activity indiscriminately directed against the suspect before such knowledge exists ought to be discouraged. It has been unsuccessfully urged that the random selection of the defendant invades constitutionally protected areas. Whiting v. United States, 321 F.d 72, 76 (Ist Cir.), cert. denied, 375 U.S. 884 (1963). Nor does the offering of an inducement in the absence of grounds to suspect the target amount to official conduct which is so offensive per se as to warrant a finding of entrapment as a matter of law. $321 \mathrm{~F} 2 \mathrm{~d}$ at 77. In Whiting, the court appears to have rejected the prior knowledge requirement altogether. See Sorrells v. United States, 57 F.2d 973, 975 (4th Cir.), rev'd, 287 U.S. 435 (1982).

o1 "[I]f the government agents suspected appellant of unlawfully dealing in narcotics, they were authorized to take steps to purchase a quantity from him, and, although the device employed was exceedingly indecent and beneath the dignity of the United States, the transaction would be sufficient to support the conviction." Wall v. United States, 65 F.2d 993, 994 (5th Cir. 1993). Implicit in such a rule is the view that the prior-knowledge requirement is a license, armed with which the government officers may do whatever they please. See Ryles v. United States, I83 F.2d 944, 946 (10th Cir.), cert. denied, 340 U.S. 877 (1950); Morei v. United States, 127 F.2d 827, 833 (6th Cir. 1942); C. M. Spring Drug Co. v. United States, 12 F.2d 852, 856 (8th Cir. 1926); United States v. Wallace, 170 F. Supp. 941 (W.D. Pa.), aff'd, 269 F.2d 394 (3d Cir. 1959); Sherman v. United States, 36 A.2d 556, 563 (D.C. Munic. Ct. App. 1944) (dissenting opinion); Note, 28 CoLUM. L. REv. 1067, 1070 (I928).

o2 Whiting v. United States, 321 F.2d 72 (1st Cir.), cert. denied, 375 U.S. 884 (1968); Whiting v. United States, 296 F.2d 512 (1st Cir. 1961).

${ }^{83}$ E.g., Childs v. United States, 267 F.2d 619, 620 (D.C. Cir.), cert. denied, 359 U.S. 948 (1958) ("probable cause is not required"); Lunsford v. United States, 200 F.2d 237, 239 (10th Cir. 1952) ("reasonable grounds to believe" prior unlawful conduct); Ryles v. United States, 183 F.2d 944, 945 (10th Cir.), cert. denied, 340 U.S. 877 (1950) (same); Morei v. United States, 127 F.2d 827, 833 (6th Cir. 1942) ("reasonable suspicion"); Wall v. United States, 65 F.2d 998, 994 (5th Cir. 1933) (“suspected"); O’Brien v. United States, 51 F.2d 674, 677 (7th Cir. 1931) ("strong suspicion'); United States v. Owens, 228 F. Supp. 300, 303-04 (D.D.C. 1964) ("good faith and ... honest belief"). 
the bait tempts the entire community, some cases suggest that there may be entrapment where the trap is grossly objectionable per se. ${ }^{84}$ Under such circumstances, the "unwary innocent" as well as the "unwary criminal" may be its catch.

\section{Causation of defendant's acts by inducement}

After acts amounting to inducement have been shown to have been performed by government agents, entrapment requires the further showing that but for the inducement, the defendant would not have perpetrated the forbidden acts. ${ }^{85}$ In the absence of proof that the crime was causally related to the inducement, the defendant is in no position to claim that the undesirable government action unfairly affected him. ${ }^{86}$

Evidence that the defendant was actually induced by the government agents is similar in kind to the proof necessary to show that the origin of the criminal plan lay in the government. In both cases, the concern is with the defendant's "predisposition." That the defendant was actually induced may be unlikely where he displayed a readiness to commit the act; and conversely, a reluctance to succumb to the government temptations may evidence an overwlielming of the will, and thus, actual inducement. . $^{\text {T }}$ Similarly, the predisposition to commit the act as demonstrated by a past pattern of criminal conduct or prior convictions is relevant, and despite the fact that access to this information is likely to be misused by the jury, it is admissible. $^{08}$ The kind of proof which evidences predisposition was set out by Judge Learned Hand to include a showing that the defendant (I) was already engaged in "an existing course of criminal conduct," (2) had "already formed a design to commit the crime or similar crimes," or (3) was willing to commit the crime "as evidenced by ready complaisance." 09

\footnotetext{
os See notes 56-57 supra and accompanying text.

os E.g., Lopez v. United States, 373 U.S. 427, 434 (1963); Sherman v. United States, 356 U.S. 369 (1958); Sorrells v. United States, 287 U.S. 435, 454 (1932); United States v. Irwin, 354 F.2d 192 (2d Cir. 1965), cert. denied, 383 U.S. 967 (1966); Accardi v. United States, 257 F.2d 168 (5th Cir.), cert. denied, 358 U.S. 883 (1958); State v. Avery, 152 Conn. 582, 211 A.2d 165 (1965).

os The requirement of causation demonstrates that the policy of the defense is not solely to check the police. Compare Whiting v. United States, 321 F.2d 72, 75 \& n.6 (1st Cir.), cert. denied, 375 Ú.S. 884 (1963): "So far as the individual defendant is concerned the defense has no logical core." 321 F.2d at 75.

${ }^{\circ}$ See, e.g., Henderson v. United States, 237 F.2d 169, 171 (5th Cir. 1956).

${ }^{\circ}$ See notes 191-34 infra and accompanying text.

"United States v. Becker, 62 F.2d 1007, 1008 (2d Cir. 1933) (Hand, L., J.). Several
} 
Origin of the criminal design

Another prerequisite to a showing of entrapment is proof that the criminal plan first originated in the mind of government agents and not in the mind of the defendant. ${ }^{70}$ It is said that the scheme must be the product of the "creative activity" of the government, for the object of the defense is to prevent "manufacturing of crime" for the purpose of instituting criminal prosecutions. ${ }^{72}$ Prior to some objective act, however, initiation of the criminal design may be difficult to establish, since overt manifestations of the defendant's state of mind are often lacking. An analysis of the cases suggests that certain types of proof constitute relevant indicia of the defendant's mental state. Thus, if the defendant initiates the suggestion of the crime to a disguised government agent ${ }^{73}$ or reacts quickly and without hesitation to a government suggestion, ${ }^{74}$ the trier of fact may infer the requisite state of mind. ${ }^{75}$ Similarly, proof

cases have purported to follow these guidelines. E.g., United States v. Jones, 302 F.2d 46 (7th Cir. 1962); Jasso v. United States, 290 F.2d 671 (5th Gir.), cert. denied, 368 U.S. 858 (1961); United States v. Sherman, 200 F.2d 880 (2d Cir. 1952).

${ }^{70}$ E.g., Sherman v. United States, 356 U.S. 369 (1958); Sorrells v. United States, 287 U.S. 435, 451 (1932); United States v. Gosser, 339 F.2d 103, 109 (6th Cir. 1964), cert. denied, 382 U.S. 819 (1965); Accardi v. United States, 257 F.2d 168 (5th Cir.), cert. denied, 358 U.S. 883 (1958); United States v. Lindenfeld, 142 F.2d 829 (2d Cir.), cert. denied, 323 U.S. 761 (1944); Morei v. United States, 127 F.2d 827, 834 (6th Cir. 1942).

A finding that the design was not conceived by the defendant is essential to the defense, since, absent such a finding, there can be no entrapment regardless of the governmental inducement. United States v. Saucedo, 346 F.2d 871 (7th Gir. 1965); Butler v. United States, 191 F.2d 433 (4th Cir. 195I); United States v. Smith, 43 F.2d 173 (S.D. Tex. 1980); People v. Estrada, 211 Cal. App. 2d 722, 27 Cal. Rptr. 605 (Dist. Ct. App. 1963). But see Waker v. United States, 344 F.2d 795 (Ist Cir. 1965).

If the defendant originates the scheme but then abandons it, and the government subsequently induces the conduct, there will be entrapment. United States v. Kloster* man, 248 F.2d 191, 195 (3d Cir. 1957); United States v. Lynch, 256 Fed. 983 (S.D.N.Y. 1918). See Marbs v. United States, 250 F.2d 514 (8th Cir. 1957).

72 Sorrells v. United States, 287 U.S. 435, 451 (1932).

7 Lopez v. United States, 373 U.S. 427, 434 (1963).

${ }^{73}$ Lopez v. United States, 373 U.S. 427 (1963); Masciale v. United States, 356 U.S. 386 (1958); United States v. Saucedo, 346 F.2d 371 (7th Cir. 1965); Reid v. United States, 334 F.2d 915 (9th Cir. 1964).

"E.g., Maestas v. United States, 341 F.2d 493 (10th Cir. 1965); Whiting v. United States, 321 F.2d 72, 77 (1st Cir.), cert. denied, 375 U.S. 884 (1963); Brainin v. United States, 314 F.2d 460 (5th Cir. 1963); Lathem v. United States, 259 F.2d 393 (5th Cir. 1958).

${ }^{75}$ Locating the origin of the criminal design is one of the more dificult factual problems connected with the defense. The defendant, of course, is free to show that he reluctantly agreed to carry out a plan proposed by the police and a product of their creative activity. See United States v. Cooper, 321 F.2d 456 (6th Cir. 1963); United States v. Accardi, 257 F.2d 168 (5th Cir.), cert. denied, 358 U.S. 883 (1958); City of Seattle v. Evans, 409 P.2d 656 (Wash. 1966). Thus, accosting a partially intoxicated citizen to induce him to obtain liquor can be entrapment. United States v. Echols, 253 
that the defendant has in the past engaged in a pattern of criminal conduct might support a finding by the trier of fact that he originated the scheme. ${ }^{76}$

The requirement that the government must initiate the criminal design has not been adopted without criticism. According to the concurring opinions in both Sorrells and Sherman, the prior record or predisposition of the defendant has no place in the doctrine, ${ }^{77}$ since the sole purpose, they contend, is to restrain the government from "enforcement of the law by lawless means." cause an equally important function of the defense is to exonerate the wronged defendant, this criticism has not prevailed.70

\section{Entrapment as to particular offenses}

Entrapment has been successfully asserted as a defense to prosecutions for a variety of crimes. No federal court has yet held that there is a crime for which the defense is inapplicable. ${ }^{80}$ Although the defense is probably employed most frequently in narcotics prosecutions, ${ }^{81}$ entrapment has been raised in prosecutions for military

Fed. 862 (S.D. Tex. 1918). A plan whereby federal officers convinced a young man to bring liquor into the United States was found to be of Government origin. United States v. Certain Quantities of Intoxicating Liquors, 290 Fed. 824 (D.N.H. 1923), 10 VA. L. REv. 316 (1924). Similarly, repeated police requests for narcotics over a long period of time may indicate government conception. Sherman v. United States, 356 U.S. 369, 373 (1958). But see People v. Toler, 26 Ill. 2d 100, 185 N.E.2d 874 (1963). A survey of factual situations in which the conception was attributed either to the defendant or to the government does little more than indicate the difficulty of discerning mental statc from objective facts. Quite appropriately, this issue usually goes to the jury. See Gorin v. United States, 313 F.2d 641, 652-54 (Ist Cir.), cert. denied, 374 U.S. 829 (1963); Hattem v. United States, 283 F.2d 339 (9th Cir. 1960), cert. denied, 365 U.S. 812 (1961).

70 E.g., Carlton v. United States, 198 F.2d 795, 797 (9th Cir. 1952).

IT Sherman v. United States, 356 U.S. 369, 382-84 (1958); Sorrells v. United States, 287 U.S. 435, 458-59 (1932). While the test of original conception is probably too vague and indefinite, it continues to be employed. E.g., Washington v. United States, 275 F.2d 687, 690 (5th Cir. 1960); Childs v. United States, 267 F.2d 619 (D.C. Cir. 1958), cert. denied, 359 U.S. 948 (1959); Ryles v. United States, 183 F.2d 944 (10th Cir. 1950); Weathers v. United States, 126 F.2d 118 (5th Cir. 1942).

${ }^{78}$ Sherman v. United States, supra note 77 , at 380 (concurring opinion).

${ }^{70}$ See note 114 infra and accompanying text. But see Hansford v. United States, 308 F.2d 219, 228-24 (D.C. Cir. 1962).

${ }^{80}$ For a listing of crimes, in the trials for which entrapment has been used as a defense, see Annot., 86 A.L.R. 263 (1933); Annot., 66 A.L.R. 478 (1980); Annot., 18 A.L.R. 146 (1922).

${ }^{81}$ See Annot., 39 A.L.R.2d 883 (1954); Note, 38 NotrE DAME LAw. 741 (1963). 
security violations, ${ }^{82}$ counterfeiting, ${ }^{83}$ perjury, ${ }^{84}$ income tax offenses, ${ }^{80}$ gambling and conducting lotteries, ${ }^{86}$ smuggling, ${ }^{87}$ liquor law violations, ${ }^{88}$ dealing in gold coins, ${ }^{89}$ mail statute violations, ${ }^{90}$ war restrictions violations, ${ }^{91}$ and sexual offenses. ${ }^{92}$ As this list indicates, official activity which resembles entrapment usually occurs in the detection of continuing criminal conduct. Nevertheless, it is significant that apart from liquor and narcotics violations, attempts to raise the defense have been singularly unsuccessful. ${ }^{93}$

Whether there may be-certain crimes which are so heinous or detrimental to the public safety that the defense of entrapment will be unavailable to their perpetrators is an open question ${ }^{94}$ and, possibly, a moot one. It is doubtful that government agents would so thoroughly abuse official discretion by victimizing an innocent citizen merely to procure a prosecution.

\section{Theoretical Basis}

The defense of entrapment in the federal courts exists without any judicially articulated basis in the Constitution. With the exception of one unreasoned case in which the court declared that

${ }^{82}$ Romero v. Squier, 133 F.2d 528, 532 (9th Cir.), cert. denied, 318 U.S. 785 (1943).

${ }^{88}$ United States v. Head, 353 F.2d 565 (6th Cir. 1965); United States v. Sferas, 210 F.2d 69, 71 (7th Cir.), cert. denied, 347 U.S. 935 (1954).

8* United States v. Remington, 208 F.2d 567, 570 (2d Cir. 1953), cert. denied, 347 U.S. 913 (1954).

${ }^{85}$ Cohen v. United States, 201 F.2d 386, 394 (9th Cir.), cert. denied, 345 U.S. 951 (1953).

${ }^{80}$ Cook v. United States, 193 F.2d 373 (D.C. Cir. 1951).

${ }^{87}$ Murray v. United States, 250 F.2d 489, 492 (9th Cir. 1957), cert. denied, 357 U.S. 932 (1958).

${ }^{88}$ Williamson v. United States, 311 F.2d 441 (5th Cir. 1962).

${ }^{80}$ Farber v. United States, 114 F.2d 5, 10 (9th Cir.), cert. denied, 311 U.S. 706 (1940)

00 Weatbers v. United States, 126 F.2d 118 (5th Cir. 1942).

${ }^{01}$ Shaw v. United States, 15I F.2d 967, 969 (6th Cir. 1945).

${ }^{02}$ Both the kinship and the distinction between the consent defense and the entrapment defense can be seen most readily in cases involving sexual offenses. Thus, where the charge is homosexual assault, the accused may prevail not because of entrapment, although the court may use the word, but because the consent of the government agent vitiated an element of the offense. E.g., Guarro v. United States, 237 F.2d 578 (D.C. Cir. 1956); McDermett v. United States, 98 A.2d 287, 290 (D.C. Munic. Ct. App. 1953). However, where the offense is procuring, pandering, or prostitution it would appear that entrapment may be an appropriate defense insofar as the bellhop. night clerk, or woman, not predisposed, succumbs to the inducement of the agent. E.g., People v. West, 139 Cal. App. 2d 923, 293 P.2d 166 (Dist. Ct. App. 1956); Cooper v. State, 162 Tex. Crim. 624, 288 S.W.2d 762 (1956). See Annot., 52 A.L.R.2d 1194 (1957). As to abortion, see Annot., 53 A.L.R.2d 1156 (1957).

${ }^{08}$ In every case cited in notes $83-88,90-92$, the conviction was affirmed.

' See Sorrells v. United States, 287 U.S. 435, 451 (1932). See also MOdEL Penal CODF. 
ignoring a defendant's allegation of entrapment would be a violation of due process, ${ }^{85}$ the courts have balked at elevating the defense to constitutional dimensions. ${ }^{98}$ The Supreme Court, in recognizing the doctrine, has relied upon a unique application of statutory construction $^{97}$ which, however, is not without due process overtones. ${ }^{08} \mathrm{~A}$ host of commentators ${ }^{89}$ have suggested a variety of constitutional guaran-

\$2.13 (3) (Proposed Official Draft 1962); Model Penal Code \$2.10 (3), comment (Tent. Draft No. 9, 1959).

os Banks v. United States, 249 F.2d 672, 674 (9th Cir. 1957). While the court indicated that a conviction based upon acts which also support a finding of entrapment might violate due process, it relied in part upon the possibility that defendant might have been denied his constitutional right to counsel. The case was remanded to the district court where the claim of entrapment was found without merit. The second conviction was affirmed, Banks v. United States, 258 F.2d 318 (9th Cir.) (per curiam), cert. denied, 358 U.S. 886 (1958), and the claims that there were constitutional bases for the defense were rejected.

- Two unreasoned cases have directly held that freedom from entrapment is not guaranteed by the Constitution. United States v. Bailey, 381 F.2d 218 (7th Cir. 1964); Stanley v. United States, 299 F.2d 765 (9th Cir. 1956). Nor does the giving of insufficient instructions which vitiate the defense invade the defendant's constitutional rights. Simmons y. United States, 302 F.2d 71, 78-79 (3d Cir. 1962).

Soliciting the commission of crime does not invade the constitutional rights of the victim. Whiting v. United States, 321 F.2d 72, 76 (1st Cir.), cert. denied, 375 U.S. 884 (1963); see United States v. Locklear, 237 F. Supp. 895, 898-99 (N.D. Cal. 1965). However, one court has indicated that "police methods designed to tempt innocent persons into crime are as objectionable as the coerced confession and the unlawful search." Accardi v. United States, 257 F.2d 168, 172 (5th Cir.), cert. denied, 358 U.S. 883 (1958). See United States ex rel. Toler v. Pate, 332 F.2d 425 (7th Cir.), cert. denied, 379 U.S. 858 (1964); Note, 74 YALE L.J. 942, 949 n.31 (1965). But see United States ex rel. Hall v. Illinois, 329 F.2d 354 (7th Cir.), cert. denied, 379 U.S. 891 (1954).

In Raley v. Ohio, 360 -U.S. 428, 498 (1959), 5 N.Y.L.F. 439, and Cox v. Louisiana, 379 U.S. 559 (1965), The Supreme Court, 1964 Term, 79 HaRv. L. REv. 103, 152, 40 Tulane L. REv. 185, the Court spoke of "entrapment" by states as a violation of due process, but in both cases it seems clear that, even though Sorrells was cited, the Court did not mean entrapment as a word of art.

It has been argued that, while the courts do not employ constitutional bases in theory, they do so in fact. See Cowen. The Entrapment Doctrine in the Federal Courts, and Some State Court Comparisons, 49 J. CRim. L., C. \& P.S. 447, 449 (1959).

${ }^{07}$ See Sorrells v. United States, 287 U.S. U.S. 485, 448-50 (1982). "Congress could not have intended that its statutes were to be enforced by tempting innocent persons into violations." Sherman v. United States, 356 U.S. 369, 372 (1958).

${ }^{\circ 8}$ Exemplary of the language of Sorrells v. United States, 287 U.S. 435 (1932), is the following: "If the requirements of the highest public policy in the maintenance of the integrity of administration would preclude enforcemeut of the statute in such circumstances as are present here, the same considerations justify the conclusion that the case lies outside the purview of the Act and that its general words should not be construed to demand a proceeding at once inconsistent with that policy and abhorrent to the sense of justice." 1d. at 448-49. "To construe statutes so as to avoid absurd or glaringly unjust results, foreign to the legislative purpose, is . . a traditional and appropriate function of the courts." Id. at 450.

¿\% See, e.g., Cowen, supra note 96, at 449; Rotenberg, The Police Detection Practice of Encouragement, 49 VA. L. REv. 871, 888-84 (1968); Comment, 1964 U. ILL. L.F. 821; Note, 74 Yale L.J. 942 (1965). But see Note, 45 B.U.L. Rev. 542, 549-55 (1965). 
tees on which to bottom the defense, including due process, ${ }^{100}$ illegal search and seizure, ${ }^{101}$ and coerced confessions. ${ }^{102}$ It is also possible

${ }^{100}$ The Supreme Court has indicated that, before criminal liability can be established, due process requires that the defendant perform some act. Robinson v. California, 370 U.S. 660 (1962). It has been rather tenuousiy argued that unlimited power to solicit illegal acts in net effect eliminates the requirement of an act since the police have it in their power to turn almost anyone into a criminal by choosing a means to exploit his particular weakness. See Note, 74 YaLE L.J. 942, 947 (1965). Similarly, the Court has held that the requirement of mens rea may be abolished consistently with due process only in certain limited situations. E.g., Lambert v. California, 355 U.S. 225 (1957); Morissette v. United States, 342 U.S. 246 (1952). It has been unconvincingly suggested that there is no significant difference between abolishing mens rea as a necessary element to crime and implanting, through entrapment, the required mental state. See Note, 1964 U. ILL. L.F. 821, 826.

There is a distinct similarity between the terms used to describe the evils of entrapment and those used to designate governmental conduct constituting a violation of due process. E.g., Butts v. United States, 273 Fed. 35 (8th Cir. 1921) ("unconscionable"); Rochin v. California, 342 U.S. 165, I72 (1952) ("conduct that shocks the conscience'7; see Cowen, supra note 96, at 449.

Regardless of whether all entrapments are per se violations of due process, one may reasonably assume that facts comprising a particular entrapment might involve conduct of the police so outrageous as to violate due process. Compare United States ex rel. Toler v. Pate, 332 F.2d 425, 427-28 (7th Cir. 1964) (concurring opinion): “To me, however, it seemed clear that the circumstances of an entrapment case such as shown by this record are so, offensive to the conscience of our society that it must be embraced within the fluid concept of the due process requirement." (Emphasis supplied.) But see United States v. Morrison, 348 F.2d 1003, 1004 (2d Cir.), cert. denied, 382 U.S. 905 (1965); Whiting v. United States, 321 F.2d 72, $76-77$ (1st Cir.), cert. denied, 375 U.S. 884 (1963).

${ }^{101}$ The Supreme Court in Sherman recognized that when an otherwise innocent person is induced to commit a crime "stealth and strategy become as objectionable police methods as the coerced confession and unlawful search." 356 U.S. at 372 . It has been argued than an officer, acting only on suspicion, who induces a person to commit an offense is improperly "searching" for a crime. Similarly, the values of privacy, dignity, and personal integrity which underlie the fourth amendment might limit the government's right to search for offenses. See Note, 74 YaLE L.J. 942 (1965). See also Rotenberg, The Police Detection Practice of Encouragement, 49 VA. L. REV. 871, 883 (1963); Note, 1964 U. ILL. L.F. 821, 823. But see Note, 45 B.U.L. REv. 542, 552 (1965).

A search is permitted only where incident to a lawful arrest or where there is probable cause that an offense has been committed and that the person searched has committed the offense, and even then, only under certain circumstances. Brinegar v. United States, 398 U.S. 160 (1949); Husty v. United States, 282 U.S. 694 (1931); Steele v. United States, 267 U.S. 498 (1925); Carroll v. United States, 267 U.S. 132 (1925). In the case of entrapment, however, the government commences its efforts against the defendant before the act for which he is to be prosecuted even occurs. Moreover, to justify entrapment, the government need not show that it had probable cause that the target of its efforts committed a crime, but merely that it had reasonable grounds to suspect a course of criminal behavior in the past. See notes 59.63 supra and accompanying text.

It has been suggested that additional safeguards be provided for the prospective viction of entrapment such as requiring that the government procure a "warrant" from a magistrate upon a showing of the grounds for suspicion or probable cause. Donnelly, Judicial Control of Informants, Spies, Stool Pigeons, and Agent Provocateurs, 60 YALE L.J. 1091, 1114 n.65 (1951). If such a procedure were adopted, it might serve 
that the victim of an entrapment could convincingly assert that the government action has deprived him of equal protection of the laws. ${ }^{103}$ At present, however, these assertions have been consistently rejected by the courts, which have found the confines of the existing defense sufficiently broad to accomplish the desired results. ${ }^{104}$

only to underscore the dubious foundation for the government activity, since it would graphically illustrate in many cases the weakness of the government's evidence and the baselessness of its suspicion.

While it might be urged that the different consequences resulting from a finding of entrapment on the one hand and an illegal search on the other-namely, excusing the offense as opposed to excluding evidence-justify the different standards applied to the government's prior knowledge, this position would appear to put the cart before the horse.

${ }^{102}$ It has been argued that there is some analogy between entrapment and coerced confessions. See Note, 1964 U. ILL. L.F. 821, 824; Note, 74 XALE L.J. 942, 949-52 (1965). "The basic objectives of solicitation and interrogation are functionally equivalent," namely, to induce the defendant to supply evidence of his guilt. Id. at 950. "The only meaningful difference is that in the case of solicitation police disguise their identity and elicit non-verbal conduct which the defendant does not realize will be used against him." Ibid. If overbearing a person's will to force him to make an inculpatory statement or tempt him to do so is forbidden, then overbearing a person's will to get him to commit an offense or tempting him to do so might also be forbidden.

The distinctions between coerced confessions and entrapment, however, far exceed the similarities. The essential difference between words and conduct is significant for purposes of the confession rule. $\$$ WIGMORE, EvidENCE \$ 821, at 298-99 (9d cd. 1940). But see Schmerber v. California, 384 U.S. 757 (1966). In addition, the nature of the inducement involved in the usual entrapment cases differs in many respects from the coercion incident to an illegal confession. Accordingly, the degree of coercion suffcient to invalidate a confession is very slight, Ziang Sun Wan v. United States, 266 U.S. 1,14 (1924), whereas the induccment necessary to establish entrapment must be "untoward or unusual." Leon v. United States, 290 Fed. 384 (9th Cir.), cert. denied, 263 U.S. 710 (1929); see United States v. Whiting, 321 F.2d 72, 76-77 (5th Cir.), cert. denied, 375 U.S. 884 (1963).

${ }^{203}$ Because in the case of an entrapment police activity directed at the victim begins prior to the commission of the act for which he is to be prosecuted, it is clear that the government has selected the defendant upon some quantum of knowledge. While the knowledge required has variously been referred to as "probable cause" or "reason. able suspicion," see notes 59-63 supra, the question for purposes of the guarantees of the equal protection clause is whether the basis for the government action is "reason. able" or, on the other hand, "arbitrary." If the selection of the victin were made arbitrarily, it would seem that full equal protection of the laws had been denied. See Kellett, The Expansion of Equality, 37 So. CAL. L. REv. 400 (1964); Tussman \& tenBroek, The Equal Protection of the Laws, 37 CALrF. L. REv. 341 (1949); Comment, 61 Colum. L. REv. 1103, 1120-22 (1961).

104 The defense of entrapment in the federal courts, existing as it docs by reason of a rule of statutory construction, may, for that very reason, contain certain constitutional overtones. In construing a statute as not encompassing acts committed as a result of entrapment as the Court did in Sorrells and Sherman, it is arguable that the Court was employing an established rule of statutory construction; namely, statutes are to be construed so as to avoid running afoul of constitutional safeguards. E.g., Crowell v. Benson, 285 U.S. 22, 62 (1932). Thus, it is possible that constitutional guarantees chart the permissible limits, albeit amorphous, of government conduct amounting to entrapment. 
In addition to the fact that there has been no accepted constitutional basis for entrapment, there has been little agreement among renowned jurists as to the theory which underpins the defense. ${ }^{105}$ Earlier cases relied upon analogies to consent or estoppel, ${ }^{100}$ but the reasoned opinions seemed to sense the flaws in these principles. ${ }^{107}$ The doctrinal kinship to the defense of coercion has also been suggested, ${ }^{108}$ but that theory is, at best, only relevant, and then only remotely, in those occasional cases where the inducement amounts in fact to a threat. ${ }^{108}$ It was recognized at an early date that the soundest approach to the distillation of a theory lay in treating the defense as sui generis and independent of traditional criminal theory. 110 Thus, the courts announced that "public policy" required the reversal of convictions procured by entrapment.11 Behind expressed avowals that allowing entrapped convictions to stand would displace public confidence in the law ${ }^{112}$ lay two related inter-

${ }^{108}$ Four Justices of the Supreme Court characterized the existing entrapment doctrine as being "without the formulated basis in reason that it is the first duty of the courts to construct." Sherman v. United States, 356 U.S. 969, 378 (1958) (concurring opinion). See Rotenberg, supra note 99, at 903 (indicating the need for continuing research).

100 Consent: United States v. Whittier, 28 Fed. Cas. 591 (No. 16688) (C.C.E.D. Mo. 1878). See also Guarro v. United States, 237 F.2d 578 (D.C. Cir. 1956); note 93 supra.

Estoppel: O'Brien v. United States, 51 F.2d 674 (7th Cir. 1931), 45 Harv. L. Rev. 381. Estoppel has been used in a generic sense to denote the underlying policies of entrapment. Newman v. United States, 299 Fed. 128, 131 (4th Cir. 1924).

${ }_{10}$ Both the majority and the minority opinions in the leading case recognized the inadequacy of the doctrine. Sorrells v. United States, 287 U.S. 435, 448-50 (1932); id. at 455 (concurring opinion). The use of a word like "estoppel," which possesses a technical meaning, can only lead to confusion. See Sherman v. United States, 36 A.2d 556, 563 (D.C. Munic. Ct. App. 1944) (dissenting opinion).

${ }_{108}$ See United States v. Lynch, 256 Fed. 983 (S.D.N.Y. 1918) (element of threat seemingly important). Coercion and entrapment are undoubtedly related in that both concern behavior of third persons inducing the defendant to commit proscribed acts, but entrapment is distinguishable in that the inducement is an offer of benefit, rather than a threat to a vital personal interest. The analogy might be useful, however, as a basis for limiting the application of entrapment to certain offenses. See notes 80,94 supra and accompanying text.

100 United States v. Lynch, supra note 108.

${ }^{110}$ Sorrells v. United States, 287 U.S. 435,446 (1932); id. at 454-55 (concurring opinion).

${ }_{11 x}$ Although the cases often spoke of public policy, there was little effort to articulate the particular policy offended. Id. at 454 (concurring opinion); see Butts v. United States, 273 Fed. 35, 38 (8th Cir. 1921); Woo Wai v. United States, 223 Fed. 412, 415 (9th Cir. 1915).

11s Sherman v. United States, 356 U.S. at 380 (Frankfurter, J., concurring): "Public confidence in the fair and honorable administration of justice, upon which ultimately depends the rule of law, is at stake." See Sorrells v. United States, supra note 110, at 446. 
ests: fairness to the victim of the entrapment and discouragement of official abuses. ${ }^{118}$

Even after the rationale of the defense became clear, the authority by which the courts could ignore violations of the criminal statutes remained to be settled. The majority of the Court in Sorrells erected a rule of statutory construction, holding that Congress could not have intended to subject the victim of an entrapment to criminal sanctions. ${ }^{114}$. While Sherman $v$. United States ${ }^{115}$ made it clear that the technique adopted in Sorrells represents the law, the device adopted there has not been unanimously received. The concurring Justices in Sorrells, through Mr. Justice Roberts, refused to adopt the obvious fiction of statutory construction and rested their conclusion instead upon an assertion that the courts have inherent power to refuse to become instruments of injustice. ${ }^{110}$ Recognition of entrapment became an exercise of self-protection. The minority views in Sorrells and Sherman have been well received by the commentators ${ }^{117}$ and apparently have mustered some support in the courts of appeals. ${ }^{118}$

\section{Evidentiary Problems Connected with the Defense}

In prosecutions where the defense of entrapment is raised, the introduction of evidence on the relevant issues has created a body of evidence law which differs from the normal rules. The issues

${ }^{218}$ It has been said that law enforcement officers ought to prevent crime, not create it. E.g., O'Brien v. United States, 51 F.2d 674, 677 (7th Cir. 1931); United States v. Echols, 258 Fed. 862,863 (S.D. Tex. 1918). The government ought not be allowed to procure an offense for the purposes of prosecuting the perpetrator. E.g., Sagansky v. United States, 358 F.2d 195, 202 (1st Cir. 1966); United States v. Wray, 8 F.2d 429, 430 (N.D. Ga. 1925). Other courts look to the defendant's plight and revolt against the unfaimess perpetrated upon him. Henderson v. United States, 237 F.2d 169 (5th Cir. 1956). But see Whiting v. United States, 321 F.2d 72, 75 \& n.6 (1st Cir.), cert. denied, 375 U.S. 884 (1963).

114287 U.S. at $446-49$. For an earlier case adopting the same technique, see O'Brien v. State, 6 Tex. Crim. 665 (1879).

${ }^{116} 356$ U.S. 369 (1958).

118287 U.S. at $454-55$ (concurring opinion).

${ }^{117}$ See Cowen, supra note 96, at 449; Donnelly, supra note 102, at 1112; Williams, The Defense of Entrapment and Related Problems in Criminal Prosecution, 28 FORD. haM L. REv. 399, 417 (1959); 46 HaRv. L. REv. 848, 849 (1933); Comment, 33 N.Y.U.L. REv. 1033, 1039 (1958); Note, 26 TENN. L. Rev. 554, 558 (1959). But see Mikell, The Doctrine of Entrapment in the Federal Courts, 90 U. PA. L. REv. 245, 260 (1942); Note, 73 Harv. L. REv. 1333 (1960).

113 See United States v. Morrison. 348 F.2d 1003, 1004 (2d Cir. 1965); Whiting v. United States, 321 F.2d 72, $7 \tilde{5}$ (1st Cir.), cert. denied, 375 U.S. 884 (1963); Williamson v. United States, 311 F.2d 441 (5th Cir. 1962); Accardi v. United States, 257 F.2d 168, 172 \&. n.5 (5th Cir.), cirt. denied, 358 U.S. 883 (1958). 
which have prompted these aberrations are the defendant's "predisposition" and the role which the government entrapper plays in procuring the proscribed act.

\section{Proof of predisposition}

Because the defense of entrapment rests upon a finding that the government agents masterminded and elicited the forbidden acts, the predisposition of the defendant to commit the acts in the absence of government activity becomes relevant. ${ }^{119}$ The broad concept of predisposition is most clearly seen as an intermediate fact from which inferences can be drawn as to the conceptually distinct ultimate facts of prior governmental knowledge, ${ }^{120}$ origin of the conception, ${ }^{121}$ and causal consequences of the inducement. ${ }^{122}$ Evidence relevant on the issue of predisposition may include both direct and hearsay evidence of the defendant's prior criminal convictions, prior criminal activity for which he was not convicted, and general character. ${ }^{123}$ It is not

${ }^{110}$ E.g., Matysek v. United States, 321 F.2d 246, 248 (9th Cir. 1963), cert. denied, 376 U.S. 917 (1964); Trent v. United States, 284 F.2d 286, 288 (D.C. Cir. 1960), cert. denicd, 365 U.S. 889 (1961); Accardi v. United States, 257 F.2d 168, 173 (5th Cir.), cert. denied, 858 U.S. 883 (1958); Bloch v. United States, 226 F.2d 185, 188 (9th Cir. 1955), cert. denied, 350 U.S. 948 (1956).

${ }^{120}$ See, e.g., Whiting v. United States, 321 F.2d 72, 75 (1st Cir.), cert. denied, 875 U.S. 884 (1968).

121 See, e.g., United States v. Head, 353 F.2d 566, 568 (6th Cir. 1965); Trent v. United States, 284 F.2d 286, 288 (D.C. Cir. 1960), cert. denied, 865 U.S. 889 (1961).

122 Recognition, or even acceptance, of the fact that "predisposition" is an intermediate rather than an ultimate fact has not been accomplished. However, this conceptually important distinction is implicit in the cases. Evidence of predisposition will support an inference, either permissible or conclusive, that government conduct amounting to inducement did not cause the criminal act or that the defendant actually conceived the crime. Such evidence, if known in advance by the government, may also be the basis for a finding that there was a reasonable suspicion that the defendant was engaged in criminal activity.

In most cases, proof of predisposition will conclusively establish that the inducements did not cause the criminal activity, E.g., Johnson v. United States, 317 F.2d 127, 129 (D.C. Cir. 1968). But see United States v. Klosterman, 248 F.2d 191 (3d Cir. 1957).

12: E.g., Heath v. United States, 169 F.2d 1007, 1010 (10th Cir. 1948). See Model. Penal CODE \$2.10, comment (Tent. Draft No. 9, 1959): "Under the existing law, which puts the entrapment issue to the jury, the defense can be raised only at a great price to the defendant. If entrapment is the inducing of an 'innocent' person to a criminal act, the character of the accused becomes a matter for judicial attention. Is the defendant a strayed lamb or an ensnared wolf? With character in issue, it becomes proper to inquire into prior convictions, and the general reputation of the accused. Even a later offense may be taken into account in estimating disposition to commit an earlier one. Because the defense may be established under a general plea of not guilty, proof of a prior conviction is proper on the part of the government when it is clear that the defense of entrapment will be invoked. Thus many defendants will find 
essential that the government introduce such evidence to demonstrate predisposition, ${ }^{124}$ since the fact can also be proved by more direct proof. ${ }^{125}$ However, a mere showing that the defendant had previously engaged in illegal conduct does not preclude the defense. ${ }^{126}$

Of course, it is necessary that the defense of entrapment be raised before the otherwise inadmissible predisposition evidence may be introduced. ${ }^{127}$ Thus, if the defendant does not rely on entrapment ${ }^{128}$ or takes the defense out of the case, ${ }^{128}$ the damaging evidence must be excluded. Where the government introduces the evidence before the defendant raises the issue, any error thereby made will be cured if the defendant, at a later time, raises the issue. ${ }^{130}$

Courts are generally receptive to predisposition evidence of past

that they are deprived of the general rule prohibiting reference to evidence of other crimes."-

1st E.g., Young v. United States, 286 F.2d 13, 15 (9th Cir. 1960), cert. denied, 366 U.S. 970 (1961); Lathem v. United States, 259 F.2d 993 (5th Cir. 1958); United States v. Masciale, 236 F.2d 601 (2d Cir. 1956), aff'd, 956 U.S. 386 (1957). In Young, the Ninth Circuit noted that requiring the government to show prior convictions would "in effect give the [defendant] . . . 'one free shot' before he could be convicted." 286 F.2d at 15 .

126 Predisposition may be established by proof that the defendant reacted quickly and without hesitation to the government suggestion. See Lathem v. United States, supra note 124. The methods of proving predisposition vary with the crime. Com. pare United States v. Klosterman, 248 F.2d 191, 196 (3d Cir. 1957) (bribery convic. tion): "It is our view that in a crime of this nature, occurring as it does usually only once and not in a series, is not like the sale of narcotics or of contraband liquor, so it is virtually impossible to show a course of conduct [sic]."

120 "A criminal record is relevant in regard to a predisposition or propensity, but does not preclude the defense of entrapment." Hansford v. United States, 303 F.2d 219, 222 (D.C. Cir. 1962). See Henderson v. United States, 261 F.2d 909, 912 (5th Cir. 1959) (by implication). In Jasso v. United States, 290 F.2d 671 (5th Cir.), cert. denied, 368 U.S. 858 (1961), the court approved an instruction to the jury which required the defendant to be free of past guilt in order to raise the defense. However, the court did indicate in dictum that defendant could still raise the defense if he showed that he had abandoned the path of criminality before the government inducement. 290 F.2d at 674.

${ }_{127}$ In United States v. Costner, 359 F.2d 969, 974 (6th Cir. 1966), one of the defendants did not raise the defense of entrapment, and the court held that it was reversible error for the judge to have admitted otherwise inadmissible predisposition evidence. See Jasso v. United States, supra note 126 (objections to hearsay evidence of predisposition waived when defendant pleads entrapment).

128 Neill v. United States, 225 F.2d 174, 178 (8th Cir. 1955).

120 In Nutter v. United States, 289 Fed. 484 (4th Cir. 1923), the defendant claimed entrapment, but also denied commission of the offense. The court held that the denial precluded the defense of entrapment and reversed the lower court conviction because predisposition character evidence was erroneously admitted where entrapment was not properly in issue.

${ }^{180}$ United States v. Sherman, 240 F.2d 949, 952 (2d Cir. 1957), rev'd on other grounds, 356 U.S. 369 (1958); Heath v. United States, 169 F.2d 1007, 1010 (10th Cir. 1948); see Reece v. United States, 131 F.2d 186 (5th Cir. 1942). 
convictions despite the fact that they are dissinuilar to the instant crime $^{131}$ or quite removed in time. ${ }^{132}$ Realizing that the jury might well misuse such information, some precautions have been interjected. One court has excluded uncorroborated evidence of prior offenses by applying a calculus of relevancy, finding the value of the evidence outweighed by the danger of prejudice. ${ }^{133}$ However, the usual method by which courts control the dangers connected with predisposition evidence is to give cautionary instructions which direct the jury to consider it only on the issue of predisposition and not to prove the mens rea or the commission of the act. ${ }^{134}$

\section{Entrappers and informers}

The presence as a witness of the government's agent who had solicited the defendant's conduct is often necessary to corroborate or refute the defendant's account of the alleged entrapping acts. The government may be reluctant to call the agent, who all too frequently is an unsavory character whose value derives from his ability to work his way into the confidence of those engaged in criminal activity. At best such a person makes a poor witness and usually underscores the objectionable nature of the government machinations. ${ }^{135}$

While it has been held that the failure by the government to call the entrapper is not reversible error, ${ }^{136}$ the prevailing rule seems to be that, since he is usually the only other person who can shed light on the issue, the government must either produce the agent or

${ }^{181}$ Carlton v. United States, 198 F.2d 795, 797-98 (9th Cir. 1952), 81 Chr.-Kent L. Rev. 246 (1953). But see note 183 infra and accompanying text.

182 Trice v. United States, 211 F.2d 513, 516 (9th Cir.), cert. denied, 348 U.S. 900 (1954); Carlton v. United States, supra note 131, at 799-800. But see Sherman v. United States, 356 U.S. 369,375 (1958) (remote character evidence insufficient in itself to prove predisposition).

${ }^{183}$ This enlightened position is taken in Hansford v. United States, 303 F.2d 219 (D.C. Cir. 1962), where highly infammatory but minimally relevant evidence was excluded. See United States v. Costner, 359 F.2d 969, 974 (6th Cir. 1966).

2s' See Washington v. United States, 275 F.2d 687, 690 (5th Cir. 1960). See also Sauvain v. United States, 81 F.2d 782 (8th Cir. 1929).

2ss See generally Donnelly, Judicial Control of Informants, Spies, Stool Pigeons, and Agent Provacateurs, 60 YALE L.J. 1091 (1951).

${ }_{180}$ Washington v. United States, 275 F.2d 687, 690 (5th Cir. 1960): "The government is not required to call all witnesses who are competent to testify .... The principle applies even to a special agent or informer who participated in the transaction." See also Trent v. United States, 284 F.2d 286 (D.C. Cir.), cert. denied, 365 U.S. 889 (1960). In O'Brien v. United States, 51 F.2d 674 (7th Cir. 1931), although the Government's failure to call the informer-entrapper was not error, the court noted that "the evidence has been examined [on appeal] with that fact as background." Id. at 676. 
show cause why it could not. ${ }^{137}$ It would logically follow that if the government informs the defendant that it will not produce the agent, the defendant must object to preserve the error. ${ }^{138}$ To assure the presence of the agent whose testimony may be crucial to a defendant who is not likely to be believed, the court may call the agent sua sponte ${ }^{139}$ and at least should grant a continuance to allow the defendant to call him. ${ }^{140}$

A practice which the federal courts have eschewed has been the employment of entrapping agents on a contingent fee basis. Under such an arrangement of bounties, courts fear that the likelihood of snaring an innocent is unhealthily enhanced. ${ }^{141}$ In Williamson $v$. United States ${ }^{142}$ the court revolted at the contingent fee system and held that, absent government proof of some "justification," use of this method would, in itself, render the government conduct so objectionable as to constitute entrapment. ${ }^{143}$ Subsequent cases, however, have found sufficient justification where the government had prior knowledge of defendant's unlawful conduct ${ }^{144}$ or where the

1st United States v. Clarke, 220 F. Supp. 905, 908 (E.D. Pa. 1963): "We think common fairness made it the Government's duty to produce [the agent] . . at the trial, or, failing that, to show that reasonable efforts to produce him were fruitless." In Clarke, as in most similar cases, the agent was deemed to be a key witness. $C f$. United States v. Ramsey, 220 F. Supp. 86 (E.D. Tenn. 1963) (contingent fee informer). Sce also United States v. Jones, 360 F.2d 92, 95 (2d Cir. 1966) (government must provide defendant with agent's name, information of his whereabouts, and must extend "reason. able cooperation'); Velarde-Villarreal v. United States, 354 F.2d 9, 13 (9th Cir. 1965) (government must make "reasonable efforts" to produce the agent); Orfield, Privileges in Federal Criminal Evidence, 40 U. DET. L.J. 403, 421 (1963); 64 ColuM. L. REv. 359 (1964). See also Roviaro v. United States, 353 U.S. 53, 65 n.15 (1957). Production of the entrapping agent may be necessary to sustain the government's burden of proof. See Henderson v. United States, 261 F.2d 909 (5th Cir. 1959).

However, where the allegation of entrapment is patently frivolous, the government may not have to produce the agent. See United States v. Julia, 348 F.2d 915 (2d Cir. 1965). See also United States v. Joseph, 355 F.2d 483 (2d Cir. 1966) (per curiam).

1a: Compare Brown v. United States, $26 I$ F.2d 848 (9th Cir. 1958).

18. United States v. Browne, 313 F.2d 197 (2d Cir.), cert. denied, 374 U.S. 814 (1963). 110 United States v. White, 324 F.2d 814 (2d Cir. 1963).

141 In United States v. Ramsey, 220 F. Supp. 86, 90 (E.D. Tenn. 1963), the failure of the prosecution to 'produce the contingent fee agent was considered grounds for granting a new trial because it raised serious questions of "fair play."

14s 311 F.2d 441, 445 (5th Cir. 1962), cert. denied, 381 U.S. 950 (1964), 15 ALA. L. REv. 603 (1963), 49 VA. L. REv. 1021 (1963).

ss Of course the mere fact of employment does not constitute entrapment. Hayes v. United States, 112 F.2d 676 (10th Cir. 1940). The use of a confirmed narcotic offender as an informer while charges were pending against him has been criticized but found not to establish entrapment as a matter of law. Matysek v. United States, 321 F.2d 246, 249 (9th Cir. 1963), cert. denied, 376 U.S. 917 (1964).

« Hill v. United States, 328 F.2d 988 (5th Cir. 1964), 16 Syracuse L. REv. 143. 
government could give convincing reasons for the arrangement. ${ }^{145}$ Other cases have found that there is no contingent fee system merely because the agent is paid according to the "extent and quality" of his work ${ }^{146}$ or because no one person was singled out for solicitation and no per capita bounty was set. ${ }^{147}$ These distinctions appear to have effectively sapped the beneficial Williamson rule of its efficacy. In any event, the defendant would appear to be entitled to an instruction on the credibility of the agent. ${ }^{148}$

\section{RAISING the Defense}

Perhaps the most difficult problems appendant to the doctrine of entrapment emerge from the substantive and procedural questions which arise in applying the defense. Quite naturally, all of the uncertainties and inconsistencies which permeate the defense culminate in and are magnified by the attempts by courts to apply it.

\section{Procedure}

It has been broadly stated that the defense of entrapment may be investigated by the court on its own motion at any time, ${ }^{140}$ and since a primary objective of the defense is to reveal and thereafter check undesirable official conduct, one might expect courts to delve vigorously into the issue whenever the testimony suggests it. On the contrary, however, there has been an apparent reluctance by the courts to permit the defendant to raise the defense except by established procedures. While there have been efforts to adjudicate the

\footnotetext{
${ }^{145}$ See Maestas v. United States, 34I F.2d 493 (10th Cir. 1965).

${ }^{140}$ See United States v. Crim, 340 F.2d 989, 990 (4th Cir. 1965)" (per curiam) (attempt by defendant to exclude agent's testimony).

I67 United States v. Costner, 359 F.2d 969, 973 (6th Cir. 1966).

${ }^{148}$ United States v. Ginsburg, 96 F.2d 882, 886 (7th Cir.), cert. denied, 305 U.S. 620 (1938). The court held, however, that in the absence of a request for an instruction, failure to give one is not reversible error. Accord, Cratty v. United States, 163 F.2d 844 (D.C. Cir. 1947); Fletcher v. United States, 158 F.2d 321 (D.C. Cir. 1946) (court must caution the jury on the credibility of the witness).

Although the entrapper is not necessarily an accomplice, United States v. Becker, 52 F.2d 1007, 1009. (2d Cir. 1933), the analogy may suggest the basis for requiring a cautionary instruction because the agent, like an accomplice, may have underlying motives for wanting the defendant convicted. See Donnelly, supra note 135, at I11721; Orfield, Corroboration of Accomplice Testimony in Federal Criminal Cases, 9 VILL. L. REv. 15, 29 (1963).

160 "The violation of the principles of justice by the entrapment of the unwary into crime should be dealt with by the court no matter by whom or at what stage of the proceedings the facts are brought to its attention." Sorrells v. United States, 287 U.S. 435, 457 (1932) (concurring opinion); Strader v. United States, 72 F.2d 589, 591 (10th Cir. 1934).
} 
entrapment issue before trial by a motion to quash the indictment, ${ }^{100}$ by a motion to suppress evidence procured by entrapment, ${ }^{101}$ or by various pleas in bar, ${ }^{152}$ resolution has usually been postponed until the trial. Defendants have also sought to attack a judgment collaterally after having failed to establish the defense directly at trial or on appeal. It has been held, however, that entrapment cannot be successfully interposed by a writ of habeas corpus ${ }^{153}$ nor can it be urged in a motion to vacate the judgment under section 2255 of the Judicial Code. ${ }^{15 s}$ It is also clear that the defendant cannot avoid these rules by disguising his attack as a declaratory judgment action. ${ }^{156}$

The rules against entertaining collateral attacks are immediate products of the absence of a recognized constitutional foundation for the defense. ${ }^{156}$ Entrapment in itself is said not to involve constitutional guarantees no matter how obviously fundamental rights might seem to be abridged. Despite this general rule, which applies quite comfortably to an alleged entrapment where the government officials conducted themselves in only a moderately obnoxious fashion, it does not necessarily follow that entrapment can never be

280 United States v. Pappagoda, 288 Fed. 214 (D. Conn. 1923).

${ }^{202}$ See C. M. Spring Drug Co. v. United States, 12 F.2d 852 (8th Cir. 1926); Note, 28 Colum, L. REv. 1067, 1075 (1928). But see State v. Hochman, 2 Wis. 2d 410, 86 N.W.2d 446 (1957).

${ }^{238}$ Romero v. Squier, 133 F.2d 528 (9th Cir.), cert. denied, 318 U.S. 785 (1943); Claiborne v. United States, 77 F.2d 682 (8th Cir. 1935). In Sorrells v. United States, 287 U.S. 435 (1932), the Government's contention that entrapment must be saised by a special plea in bar was rejected. Id. at 452.

${ }^{168}$ See Benson v. California, 336 F.2d 791 (9th Cir. 1964), cert. denied, 380 U.S. 951 (1965); United States ex rel. Hall v. Illinois. 329 F.2d 354 (7th Cir.), cert. denied, 379 U.S. 891 (1964); Romero v. Squier, supra note 152. But see United States v. Mathues, 22 F.2d 979 (E.D. Pa. 1927).

${ }^{286} 28$ U.S.C. $\$ 2255$ (1964): "A prisoner in custody under sentence of a court established by Act of Congress claiming the right to be released upon the ground that the sentence was imposed in violation of the Constitution or laws of the United States ... or is otherwise subject to collateral attack, may move the court which imposed the sentence to vacate, set aside or correct the sentence. A motion for such relief may be made at "any time."

Coronado v. United States, 341 F.2d 918 (5th Cir.), cert. denied, 381 U.S. 943 (1965); United States v. Bailey, 331 F.2d 218 (7th Cir. 1964); Simmons v. United States, 302 F.2d 71 (3d Cir. 1962); Banks v. United States, 258 F.2d 318 (9th Cir.) (per curiam), cert. denied, 358 U.S. 886 (1950). Although an earlier case allowed the defendant to raise entrapment by a motion under $\$ 2255$ to vacate the judgment, there was reliance on an allegation of deprivation of the right to counsel. Banks v. United States, 249 F.2d 672 (9th Cir. 1957).

${ }^{185}$ Coronado v. United States, supra note 154.

${ }^{280}$ But see Banks v. United States, 249 F.2d 672 (9th Cir. 1957). 
so egregious as to amount to a due process violation. ${ }^{167}$ Thus, courts at least ought to permit the defendant to show that the particular official conduct which entrapped him was revolting to "fundamental notions of fair play."158

Entrapment can be and usually is raised by a plea of not guilty, ${ }^{160}$ and it is error to require a special plea in bar. ${ }^{160}$ And where entrapment appears on the conceded facts, the court may refuse to accept a guilty plea and thereafter acquit. ${ }^{161}$ However, a general motion for a directed verdict, without more, will not raise the defense so that error in failure to consider it will not thereby be preserved for appellate consideration. ${ }^{162}$

During the course of the trial the defendant can, through choice or oversight and by operation of law, remove the issue of entrapment from the case. For example, where the defendant objects to evidence offered by the government on the issue of predisposition, and the evidence is excluded, he cannot later allege error in the court's failure to acquit for entrapment. ${ }^{163}$ A very interesting, highly criticized, and apparently waning rule which operates to deprive the defendant of the defense is that one will not be permitted to deny that he has committed the offense and still rely on entrapment. In the federal courts, the Ninth Circuit Court of Appeals has been the most vigorous in the statement and application of the rule. ${ }^{164}$ Most of the other circuits have at one time endorsed the rule indicating that it is impermissibly inconsistent to argue: "I did not commit the crime, but if I did, I was entrapped."16r

\footnotetext{
${ }^{167}$ See note 100 supra. Compare Benson v. California, 396 F.2d 791 (9th Cir. 1964), cert. denied, 380 U.S. 951 (1965).

158 See note 100 supra.

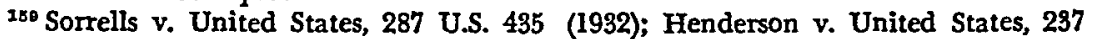
F.2d 169 (5th Cir. 1956); Wall v. United States, 65 F.2d 993 (5th Cir. 1993).

180 Sorrells v. United States, supra note 159 , at 452.

${ }^{16 x}$ United States v. Echols, 253 Fed. 862 (S.D. Tex. 1918). The court may also set aside a judgment on its own motion. United States v. Healy, 202 Fed. 349 (D. Mont. 1919).

162 United States v. Kaiser, 138 F.2d 219 (7th Cir. 1943).

168 Corcoran v. United States, 19 F.2d 901 (8th Cir. 1927).

16، See Ortiz v. United States, 358 F.2d 107 (9th Cir. 1966); Ortega v. United States, 348 F.2d 874 (9th Cir. 1965); Ramirez v. United States, 294 F.2d 277 (9th Cir. 1961); Brown v. United States, 261 F.2d 848 (9th Cir. 1958); Eastman v. United States, 212 F.2d 320 (9th Cir. 1954).

${ }^{185}$ See Silvia v. United States, 312 F.2d 145 (Ist Cir.), cert. denied, 374 U.S. 809 (1963); United States v. DiDonna, 276 F.2d 956 (2d Cir. 1960) (per curiam); United States v. Pagano, 207 F.2d 884 (2d Cir. 1953) (per curiam); Rodriguez v. United States, 227 F.2d 912 (5th Cir. 1955); Siglar v. United States, 208 F.2d 865 (5th Cir. 1954);
} 
The trend in the federal courts, however, seems to be toward the rejection of the disarming simplicity of this position. In obvious revolt against the undesirable consequences which the rule can effect $^{188}$ and in an attempt to make criminal trials searches for truth rather than contests to hide it, several courts have distinguished the inconsistency rule. One line of cases would not apply it where the evidence of entrapment is introduced by the testimony of the government's witnesses. ${ }^{187}$ Other cases have eroded the rule by restrictively defining what constitutes an impermissible inconsistency. ${ }^{108}$ Two cases, have denied that there is an inconsistency in "alternative" allegations of denial and entrapment, ${ }^{169}$ thus effectively abandoning the rule. 170

It is generally held that the defense of entrapment is affirmative and must be raised at trial, ${ }^{171}$ and a failure so to do will preclude the

United States v. Carter, 326 F.2d 951 (7th Cir. 1963); United States v. Kaiser, 198 F.2d 219 (7th Cir. 1943); Cratty v. United States, 163 F.2d 844 (D.C. Cir. 1947). See Nutter v. United States, 289 Fed. 484 (4th Cir. 1928).

The converse of the inconsistency doctrine has also been stated to the effect that raising the defense amounts to an admission of the criminal acts. See United States v. Georgiou, 383 F.2d 440 (7th Cir.) (dictum), cert. denied, 379 U.S. 901 (1964).

${ }^{200}$ While strict logic does. not uncover any possible "undesirable consequences" associated with the rule, they would appear to exist in fact. First, it might be deemed undesirable to permit the police to be insulated from censure merely because the defendant has decided, as a matter of strategy, to deny the commission of the offense in hopes that the government cannot establish it beyond a reasonable doubt. Secondly, raising the defense of entrapment opens for the government the floodgates which otherwise protect the jury from receiving highly inflammatory evidence on the issue of predisposition. Furthermore, the defendant's entrapment evidence may be wcak, as where it is. his word against an officer's. Fearing that the jury will be irreparably prejudiced by the predisposition evidence and realizing the weakness of the entrapment issue, the defendant might reasonably feel that silence is the best policy. Under such circumstances, there appears to be no compelling reason why he should not. be able to defend both against the general accusation and, by relying on entrapment, against criminal liability. In fact, justice may best be served thereby.

${ }^{20 r}$ Sears v. United States, 343 F.2d 139, 143 (5th Cir. 1965) (conspiracy to violate the liquor laws); see Notaro v. United States, 263 F.2d 169 (9th Cir. 1966).

${ }^{108}$ See Crisp v. United States, 262 F.2d 68 (4th Cir. 1958); Henderson v. United States, 237 F.2d 169 (5th Cir. 1956).

168 Hansford v. United States, 303 F.2d 219 (D.C. Cir. 1962). Crisp v. United States, 262 F.2d 68, 70 (4th Cir. 1958): "We think it perfectly proper to allow a criminal defendant to submit to the jury alternative defenses."

${ }^{170}$ In the early case of Scriber v. United States, 4 F.2d 97 (6th Cir. 1925), the court commented: "The court refused to submit the defense of entrapment, and did this on the theory that defendant's theory was inconsistent with that defense. In a proper case it would seem that defendant should have the benefit of this defense, even though such inconsistency exists." Id. at 98.

In the recent case of United States v. Bishop, 367 F.2d 806 (2d Cir. 1966), the court appeared to open the question for possible future treatment. Id. at $809 \&$ n.4.

${ }^{171}$ E.g., id. at 809.10; Ramirez v. United States, 294 F.2d 277 (9th Cir. 1961); Cratty 
defendant from interposing it on appeal. ${ }^{172}$ This rule both conserves the time of the courts and prevents the defendant from securing the exclusion of relevant but damaging evidence of predisposition which the government might offer. Similarly, the defendant must preserve any errors in the trial court's rulings by timely objections or offers of requested instructions. ${ }^{173}$ Absent the commission of plain error, ${ }^{174}$ this is the only manner in which errors will be preserved for appellate review.

\section{Questions for the court and jury}

The obscurities of the law of entrapment are also reflected in the law's designation of the institution which must decide the issue of entrapment. The question is usually one for the jury, deliberating under proper instructions, ${ }^{175}$ and it has been suggested that a refusal to submit a proper case to the jury might deprive the defendant of his right to a trial by jury. ${ }^{176}$ However, it is not deemed to be an encroachment upon the jury's prerogative for the judge to comment fairly upon the entrapment evidence. ${ }^{177}$

Although the trier of fact usually decides the issue, the defense may be established as a matter of law upon the proofs adduced ${ }^{178}$ or upon a motion for a directed verdict. ${ }^{179}$ Where the uncontroverted proof demonstrates that the defense is unavailable because, for ex-

v. United States, 163 F.2d 844 (D.C. Cir. 1947); United States v. Ginsburg, 96 F.2d 882 (7th Cir.), cert. denied, 305 U.S. 620 (1938).

${ }^{172}$ E.g., United States v. Bishop, supra note 170; United States v. Sferas, 210 F.2d 69 (7th Cir.), cert. denied, 347 U.S. 935 (1954).

${ }^{173}$ E.g., United States v. Pugliese, 346 F.2d 861 (2d Cir. 1965); Marbs v. United States, 250 F.2d 514 (8th Cir. 1957).

174 E.g., Cross v. United States, 347 F.2d 327 (8th Cir. 1965). See United States v. Pugliese, supra note 173. FED. R. CRIM. P. 52 (b) provides that "plain errors or defects affecting substantial rights may be noticed although they were not brought to the attention of the court."

${ }^{175}$ E.g., Sherman v. United States, 356 U.S. 364, 377 (1958); Sorrells v. United States, 287 U.S. 435 (1932); United States v. Head, 353 F.2d 566 (6th Cir. 1965); Banks v. United States, 348 F.2d 231 (8th Gir. 1965); United States v. Georgiou, 333 F.2d 440 (7th Cir.), cert. denied, 379 U.S. 901 (1964); Hattem v. United States, 283 F.2d 339 (9th Cir. 1960): Where there is entrapment, there is likely to be a question of the credibility of witnesses. See Note, 73 HARv. L. REv. 1333, 1344 (1960); Note, 75 Yale L.J. 942, 952-53 (1965).

${ }^{170}$ Hamilton v. United States, 221 F.2d 611 (5th Cir. 1955). The court did not, however, specify the elements of a "proper case."

${ }_{177}$ Meyer v. United States, 67 F.2d 223, 226 (9th Cir. 1993).

${ }_{178}$ E.g., Morales v. United States, 260 F.2d 939 (6th Cir. 1958); Henderson v. United States, 261 F.2d 909, 912 (5th Cir. 1958); United States v. Klosterman, 248 F.2d 191 (3d Cir. 1957); Morei v. United States, 127 F.2d 827 (6th Cir. 1942). 170 O'Brien v. United States, 51 F.2d 674 (7th Cir. 1931). 
ample, the defendant conceived the scheme or was not actually induced, the court may reject the defense. ${ }^{180}$ Similarly, if there is no evidence of entrapment at all, the jury need not be instructed since the defense cannot fairly be said to have been raised. ${ }^{181}$

The most difficult and vague aspect of finding entrapment as a matter of law concerns the type and sufficiency of evidence which will 'establish it. Entrapment has been found on the basis of the undisputed evidence of a government agent ${ }^{182}$ or on the uncontroverted evidence of the defendant. ${ }^{183}$ However, it is not error for the court to submit the issue to the jury where the credibility of the undisputed defendant is questionable. ${ }^{184}$ Where there is any conflict in the evidence, the defendant is entitled to the defense as a matter of law only if he establishes it beyond a reasonable doubt. ${ }^{185}$

\section{Allocation and quantification of burdens of proof}

Perhaps the most pregnant confusion shrouding the defense is

${ }^{180}$ See Jasso v. United States, 290 F.2d 671 (5th Cir.), cert. denied, 368 U.S. 858 (1961); Rodriguez v. United States, 227 F.2d 912 (5th Cir. 1955); Siglar v. United States, 208 F.2d 865 (5th Cir. 1954); United States v. Markham, 191 F.2d 936 (7th Cir. 1951).

Recent cases, however, have been extremely reluctant to allow the government to establish a lack of entrapment as a matter of law by proof that the defendant was predisposed. See United States v. Riley, 363 F.2d 955 (2d Cir. 1966); Sagansky v. United States, 358 F.2d 195 (1st Cir. 1966). Several sound reasons underlay this conclusion. The clear trend in the courts of appeals is to require the government to prove the defendant's propensities beyond a reasonable doubt after the defendant offers sufficient evidence of inducement. See notes 191.96 infra and accompanying text. Thus, it is concluded that where the government's burden is so heavy, it cannot be sustained as a matter of law, Sagansky v. United States, supra, at least, where the government's evidence is not uncontradicted, United States v. Riley, supra.

181 "[S]ubmission is not-required when evidence of entrapment is entirely lacking." Banks v. United States, 348 F.2d 231, 236 (8th Cir. 1965). Accord, United States v. Gosser, 339 F.2d 102 (6th Cir. 1964), cert. denied, 382 U.S. 819 (1966); Redfield v. United States, 328 F.2d 532 (D.C. Cir.), cert. denied, 377 U.S. 972 (1964); United States v. Markham, supra note 180; Hall v. United States, 46 F.2d 461 (4th Cir. 1931); Vamvas v. United States, 13 F.2d 347 (5th Cir. 1926).

${ }^{382}$ "Since the instant case . . . involves only consideration of the undisputed testi. mony of a government witness with no issue of credibility involved we conclude that submission of the issue of entrapment to the jury was improper." Marshall v. United States, 258 F.2d 94, 97 (10th Cir. 1958) (affirming conviction), rev'd on other grounds, 360 U.S. 310 (1959). See Cowen, The Entrapment Doctrine in the Federal Courls, and Some State Court Comparisons, 49 J. CRIM. L., C. \& P.S. 447, 452 (1959).

283 Sce Morales v. United States, 260 F.2d 939 (6th Cir. 1958).

28، See United States v. Thomas, 351 F.2d 538 (2d Cir. 1965).

285 "Under Sorrells, Sherman, and Masciale, the issue of entrapment is a question for the jury, unless as a matter of law the defendant has established beyond a reasonable doubt that he was entrapped." Washington v. United States, 275 F.2d 687, 689 (5th Cir. 1960). Accord, Accardi v. United States, 257 F.2d 168, 171 (5th Cir.), cert. denied, 358 U.S. 883 (1958). But see Sagansky v. United States, 358 F.2d 195 (1st Cir. 1966). 
evident in the tacks which courts have taken in assigning the burdens of proof between the defendant and the prosecution. The rules of the doctrine and the theory which supports it have an obvious and direct effect upon the determination as to who must prove what. The analytical difficulty is compounded by the conspicuous absence in some cases of any discussion of burdens of proof ${ }^{180}$ and by unresponsive statements in other cases. For example, many courts have allocated no burdens to the defendant but have merely required the government to prove guilt of the alleged crime beyond a reasonable doubt, ${ }^{187}$ or to prove no entrapment beyond a reasonable doubt. ${ }^{188}$ Another case has been somewhat more specific in placing upon the government the burdens to show "predisposition," but it has not quantified this burden nor has it placed any burdens on the defendant. ${ }^{189}$ Other cases explicitly require the inducement to be shown, presumably by the defendant, before the government assumes the burden of negating the defense. ${ }^{180}$

From this long background of confusion has come a series of more recently developed rules. born in reasoned cases which have acknowledged that the jury could be easily confused in the absence of elucidation of the standards it must apply. Under these cases, the defendant must usually establish the inducement, whereupon the burden is shifted to the government to negate the defense. ${ }^{101}$

\footnotetext{
${ }^{180}$ See, e.g., Cross v. United States, 347 F.2d 327 (8th Cir. 1965).

${ }^{187}$ E.g., Meyer v. United States, 67 F.2d 223, 226 (9th Cir. 1933); Gargano v. United States, 24 F.2d 625 (5th Cir. 1928).

188 "The Government has the burden of proving beyond a reasonable doubt that there was not an unlawful entrapment." Marbs v. United States, 250 F.2d 514, 516 (8th Cir. 1957) (quoting the district court). Accord, Ryles v. United States, 183 F.2d 944, 945 (10th Cir. 1950); O'Brien v. United States, 51 F.2d 674, 677 (7th Cir. 1931); United States v. Clarke, 224 F. Supp. 647, 652 (E.D. Pa. 1968), rev'd on other grounds, 343 F.2d 90 (3d Cir. 1965) (Government must prove crime "beyond a reasonable doubt without entrapment"). These holdings seem logically inconsistent with the Supreme Court's reasoning in Sorrells and Sherman to the effect that entrapped acts are not within the purview of the statute, and thus not crimes. They also suggest an inconsistency with the notion that entrapment is an affrmative defense. But see Note, 78 HARV. L. REV, 1933, 1344 (1960).

${ }^{280}$ United States v. Klosterman, 248 F.2d 191, 196 (3d Cir. 1957).

${ }^{100}$ Hansford v. United States, 303 F.2d 219, 224 (D.C. Cir. 1962).

${ }_{102}$ United States v. Sherman, 200 F.2d 880, 882 (2d Cir. 1952) (Hand, L., J.), 28 N.Y.U.L. REv. 1180 (1953); see Note, 64 Colum. L. REv. 359, 363 (1964); Note, 70 Harv. L. REv. 1302, 1903 (1957); Note, 44 Iowa L. REv. 578, 583 (1959). A third issue which the government may have to prove is that it had prior knowledge of the defendant's predisposition. Whiting v. United States, 321 F.2d 72 (1st Cir.), cert. denied, 375 U.S. 884 (1963). See Sagansky v. United States, 358 F.2d 195, 202 n.10 (lst Cir. 1966); notes 59.63 supra.
} 
The quantum of the defendant's and the government's respective burdens, however, differ substantially. In the Second Circuit, the defendant must, at most, prove government inducement "by a preponderance of the evidence," whereupon the burden shifts to the government which must prove "beyond a reasonable doubt" that the defendant was predisposed. ${ }^{102}$ The same rule appears to obtain in the Fifth Circuit. ${ }^{103}$ The Seventh Circuit has also required that the defendant prove inducement and then has shifted the burdens to the government, but it has not quantified the defendant's burden. ${ }^{104}$ The First Circuit requires only that the defendant sustain the burden of "coming forward with evidence," whereafter the government must disprove the defense beyond a reasonable doubt by showing predisposition. ${ }^{105}$ The Ninth Circuit, in a noble effort to avoid confusing the jury, has said that if the issue of entrapment has "fairly arisen," the government must prove predisposition to the jury beyond a reasonable doubt. ${ }^{196}$ However, the method by which the

102 "No legal authority has imposed a heavier burden on a defendant for any aspect of the entrapment issue than proof by a preponderance of the evidence.... We would not increase this burden on the defendant (if indeed he should bear any burden of proof whatever, a question we do not now reach)." (Emphasis added.) United States v. Pugliese, 346 F.2d 861, 863 (2d Cir. 1965). Accord, United States v. Bishop, 367 F.2d 806 (2d Cir. 1966). A district court in the Second Circuit had applied a more lax burden to the defendant in United States v. Silva, 180 F. Supp. 557, 558 (S.D.N.Y. 1959) ("burden of going forward").

Compare MODEl Penal CODE $\$ 2.13$ (Proposed Official Draft 1962): "A person prosecuted for an offense shall be acquitted if he proves by a preponderance of evidence that his conduct occurred in response to an entrapment." It is interesting to note that there was no mention of the extent of the defendant's burden of proof in the earlier tentative draft. Model Penal Code $§ 2.10$ (Tent. Draft No. 9, 1959).

103 Gorin v. United States, 813 F.2d 641, 654 (5th Cir. 1963): "[O]ne who raises the defense should be required not only to come forward with evidence but should also be required to establish inducement by a preponderance of the evidence."

10'United States v. Landry, 257 F.2d 425, 428 (7th Cir. 1958).

${ }^{100}$ Sagansky v. United States, 358 F.2d 195 (1st Cir. 1966). "Accordingly, if the evidence, whether elicited from the government or defense witnesses, would warrant a finding of inducement, the defendant is entitled to a charge that the government has the burden of proving beyond a reasonable doubt either that there was in fact no inducement, or that the defendant was predisposed, as we have previously defined predisposition. The evidence of inducement, or, conceivably, of the absence of predisposition, may be so strong that either or both questions must be resolved in the defendant's favor as matter of law. Conversely, of course, if the defendant fails to meet his burden of coming forward with evidence of inducement, there is no entrapment as a matter of law, and thus, nothing on that matter to go to the jury. If, as in the present case, therè was inducement as a matter" of law, then only the question of predisposition is submitted to the jury and the government has the burden of proving it beyond a reasonable doubt." Id. at 203. See Waker v. United States, 844 F.2d 795, 796 \& n.3 (1st Cir. 1965).

1"* Notaro v. United States, 363 F.2d 169 (9th Cir. 1966). "The duty of determining 
issue arises and the quantity of proof necessary for this purpose are not satisfactorily explained. These vague standards do not create as much trouble as they might since the preliminary question of whether the issue has fairly arisen is decided by the judge, and only after it is determined, does the jury pass upon predisposition evidence.

\section{Concluston}

The defense of entrapment in the federal courts continues to suffer from the absence of a cohesive theoretical basis. The uncertainties surrounding the defense are further complicated by ambivalent judicial attitudes which indicate reluctance to accept its sketchily defined basis and its results. In light of the fact that the defense is primarily applied to crimes which are frequently considered the products of ill-advised statutes, one senses that some distortion has occurred in the formulation of the doctrine. Against this background, the courts appear to be struggling toward piecemeal answers with more or less commendable consequences. Most notably, quantification and allocation of burdens of proof, appraisal of special evidentiary problems, and separation of the respective functions of court and jury are currently receiving judicial attention. Out of the morass there appear to be emerging carefully wrought rules which are not altogether consistent, a situation that may force the Supreme Court to take up the gauntlet and resolve the conflicts which are in the process of solidification.

whether or not the issue exists.is the judge's duty, not the jury's, and if the issue exists and the determination of the ultimate question of entrapment is submitted to the jury, "it is better [that the instructions not] speak in terms of the defendant having [any burden whatsoever].' [sic] . . . . The issue having appeared, it becomes the prosecution's burden to establish beyond a reasonable doubt that the accused was not entrapped into the commission of the offense." Id. at 175 . 